\title{
LAS ARMAS DE LOS CONQUISTADORES. LAS ARMAS DE LOS AZTECAS *
}

\author{
POR \\ ADA BRUHN DE HOFFMEYER
}

\section{INTRODUCCIÓN}

¿QUE clase de armas utilizaron los españoles en la conquista del Nuevo Mundo? No eran las mismas o idénticos tipos de armas en todas partes. Tampoco eran los mismos tipos y categorías que se utilizaban en aquella época en la Penínula Ibérica o en Eutopa occidental. Aunque los españoles llegaron al Nuevo Mundo con sus propias armas, fabricadas en España, en Italia, en Flandes, en Alemania - mejor dicho, en todo el mundo europeo del emperador Carlos $V$-, éstas no todas eran idóneas para los conquistadores de Méjico en el reino de los aztecas, o en Perú en el reino de los incas. Por varias razones. Las armas con que los conquistadores llegaron al Mundo Nuevo americano no eran completamente uniformes por razones económicas. Algunas eran de calidad, otras ya gastadas, en

* En este año 1985 se han celebrado con varios congresos, entre otros, en Salamanca y en Cáceres, los quinientos años del nacimiento de uno de los más grandes y más importantes conquistadores del Nuevo Mundo: Hernán Corlés, el conquistator del reino de los azlecas en Anábuac y el fundador del estado de Nueva España ( Mć́fico). Cortés era extremeño, nacido en Medellín, en la provincia de Badajoz, en Extremadura, hijo de un hidalgo llamado Martín Cortés de Monroy, un fiel servidor del rey de Castilla, Fernando el Católico. Sus padres le enviaron a la famosa Universidad de Salamanca, donde estudió durante una corta temporada para pronto embarcarse al Nuevo Mundo, a Santo Domingo, una de las Antillas, bautizada la Espanoola por Cristóbal Colón. Cortés pertenece a una época extraña, de transición, que sale de la Edad Media y entra en otra gran época, el Renacimiento español: la última Reconquista, con la expulsión de los moros de Granada por los Reyes Católicos; el envío de Colón por los mismos reyes al descubrimiento del Nuevo Mundo, y la entrada a la gran época de España bajo el emperador $C a r l o s ~ V$, en cuyo imperio el sol nunca se puso. La época de los primeros conquistadores, Cortés en Méjico en 1521 y Pizarro en Perú en 1536, fue tiempo de enormes contrastes entre grandes civilizaciones: el Renacimiento español bajo Carlos $\mathrm{V}$ y las civilizaciones casi prehistóricas de los aztecas e incas. Los contrastes eran fuertes en todos los ramos y fenómenos de la vida: raza, idioma, cultura, política, sociedad, religión, arte de guerra y armamento. Para los conquistadores, el encuentro entre su propia época y la prehistoria fue una sorpresa enorme. Tuvieron a modificar y cambiar armamento y táctica de una manera casi fundamental. Este artículo no pretende ser exhaustivo en un tema tan especial y complicaclo. Solamente tiene la intención de ofrecer una pequeña introducción a un tema muy poco tratado en la literatura sobre armas antiguas. 
malas condiciones, antiguas, fuera de moda, defectuosas, etc. Los conquistadores tuvieron en muchos casos que cambiar sus armas, más o menos modernas, pero europeas, por otras de iguales características que las que utilizaban sus adversarios, los indígenas, especialmente por el clima caluroso y húmedo, los terrenos difíciles, por el peso de sus «trajes» de hierro para hombre y para caballo y por falta de bestias de carga. Para combatir a estos pueblos fue necesario dejar las armas europeas y adoptar las usadas por los indios. Del mismo modo fue necesario cambiar su táctica y adoptar métodos del mismo estilo que los indígenas o, simplemente, vo!ver a armas y tácticas utilizadas en la época medieval en España.

En realidad tenemos muy poca literatura especializada en armología del Nuevo Mundo. El armamento y el arte de guerra de los aztecas, mayas o incas no han sido ampliamente investigados. Tampoco lo ha sido el armamento de los primeros conquistadores, a pesar de la importancia y los méritos de estos primeros exploradores y de los enormes contrastes que hay entre estos dos mundos. Existe un buen material arqueológico de las dos partes que nos puede ayudar a aclarar muchos problemas culturales e históricos de estos mundos, tan diferentes y con tan grandes contrastes.

Los conquistadores traían consigo sus armas europeas o españolas. La Real Armería, el Museo del Ejércilo y el Museo Naval, todos en Madrid, nos muestran el armamento de la época. También otros museos europeos y norteamericanos nos ofrecen información sobre tipos y categorías de la época. Respecto al armamento de los indios, los Museos de Historia Natural, de Historia en General y de Etnología o Antropología, en Europa, en Estados Unidos y en Méjico, nos brindan cumplidamente el armamento de los indios de cualquier lugar del Mundo Nuevo. Buenos ejemplares existen en el Museo de América en Madrid, que, además de objetos arqueológicos, posee algunos de los mejores y más importantes manuscritos, no sólo de la época de los primeros conquistadores, sino también de la cultura anterior a está época (Códice Maya; Tro-Cortesiano, único en el mundo al lado del Camoso Códice Maya en Dresde; Códice Post-Cortesiano [1554]; «Florentina», de Bernardino de Sahagún, y varios otros manuscritos de extraordinaria importancia). Asimismo, existe excelente material en el Museo Británico en Londres, en los Museos für Völkerkunde, en Berlín y en Hamburgo. El Museo für Völkerkunde en Viena tiene, entre sus colecciones, la preciosa adarga de plumas del famoso jefe azteca Moctezuma II. Buenas colecciones existen en los Museos de Historia Natural en Nueva York, Chicago, Filadelfia; en el Smithsonian Institution en Washington; en el Dumbarton Oakes fuera de Washington; en San Francisco y en varios otros de los estados norteamericanos de Arizona, Nuevo Méjico, Tejas y varios más. Es singularmente informativo el Péa- 
body Museum en Harvard Universicy, en Cambridge, Massacbusetls, especializado en la cultura de los mayas y probablemente una de las primeras instituciones más interesadas científicamente por los mayas, sobre todo en lo referente a su cultura temprana característica, tan en parangón con la de los aztecas y toltecas. El Peabody Museum se fundó, con los riquísimos fondos del gran mecenas norteamericano Georges Peabody, en el siglo pasado. Existen también museos y colecciones en Méjico, por ejemplo, el Museo Antropológico Nacional, y otros más en la capital, así como en oltás ciudades de la Confederación de Méjico. En Lima, en Perú, existe una colección particular, famosa en el mundo, la del señor $\mathrm{Miguel}$ Mújica Gallo: Museo del Oro y Museo de las Armas, uno con cerca de 7.000 objetos de oro y arqueología precolombina de Perú y otro con unos 5.000 importantes objetos y armas de toda América.

Al lado de las piezas arqueológicas, el arte de estas épocas, y también de las anteriores, sea en América, sea en Europa, es fuente especial de información. Pero no son los museos ni el arte europeos los que nos dan la noticia más fehaciente sobre el armamento en el Mundo Nuevo. Las numerosas fuentes literarias, con sus descripciones detalladas y sus dibujos y pinturas, especialmente en los códices indios de la época y años posteriores a la Conquista, más el arte indígena en forma de esculturas, relieves en piedra, algunas pinturas murales (por ejemplo, de Chichén-Itzá y Bonampak, en Yucatán) y la cerámica pintada de los mayas y toltecas, son las cjue nos dan una información importantísima, y eso a pesar de las muchas dificultades y problemas respecto a la interpretación de todo lo que se representa en estos monumentos e ilustraciones. Por lo que hace a los códices, varios de éstos existen en museos y bibliotecas europeos; algunos también los conocemos por facsímiles.

La mayoría de los manuales y revistas sobre armología nos ofrecen en muy pocas páginas todo el armamento de los indios de América. En general, son parcos en información. Entre la literatura antigua informativa hay que destacar las valiosas y excepcionales obras del científico, historiador y escritor norteamericano William H. Prescoll, de Massachusetts (nacido en Salem en 1796 y fallecido en Boston en 1859, colaborador en la Universidad de Harvard, Cambridge, Mass.), con sus dos grandes obras: History of the Conquest of Mexico (1843) y History of the Conquest of Peru (1847) (existen traducciones al español [Madrid, 1847 y siguientes]; las últimas ediciones son de 1901 y 1902). La historia de la conquista de Perú fue editada también en «Everyman's Library» (Londres, 1907), con muchos comentarios de gran importancia. Todavía tienen interés estas publicaciones, aunque no se las ve citadas en listas bibliográficas españolas.

Estas publicaciones, a pesar de cstar un tanto anticuadas por su estilo 
especial, que se corresponde al siglo pasado, todavía conservan su interés. Este se ha manifestado en algunas nuevas ediciones de los últimos años, dedicadas a las fiestas conmemorativas de los descubrimientos, va a hacer quinientos años, del Nuevo Mundo. El último libro, de William H. Prescott (Die Eroberung Mexicos), fue publicado en Munich en 1984 por J. H. Eberty y B. Cramer-Neuhaus en la serie «Beck'sche Sonderausgaben». Es un libro algo abreviado de la edición de Erich Marx (Leipzig, 1972).

Pocas personas extranjeras han conocido estas épocas españolas y sus fuentes literarias como Prescott, con su gran amor a España y su historia, con sus otras importantes obras sobre los Reyes Católicos y Felipe II. La inspiración de Prescott, sin duda - entre sus otras fuentes-, ha sido la primera y sensacional publicación de una de las más importantes fuentes literarias españolas, la obra del famoso monje franciscano fray Bernardino de Sabagún (1499-1590): Hisloria General de las Cosas de Nueva España, aunque Prescott ha conocido bien las otras fuentes españolas de la época. Después de estar olvidado cerca de trescientos años, este importante documento, una riquísima y auténtica fuente, fue publicado por Carlos María Bustamante en 1829 y por Lord Kingsborough en 1830, más su Antiquities of Mexico (1838-1840). Los manuscritos originales de esta obra, por Bernardino de Sahagún, se encuentran en Madrid: en el Museo de América, en el Palacio Real y en la Real Academia, más una parte en Florencia (Laurentianum), en Italia. La descripción detallada por parte de Prescott, en su History of the Conquest of Mexico, del armamento, milicia, organización militar, honores, símbolos, etc., de los aztecas parece haber sido sacada directamente de la gran obra de fray Bernardino de Sahagún, pero este gran historiador nos lo cuenta con su inspirado y característico estilo. (Esta obra está también publicada por $P$. Robredo en Méjico, 1938.) Al final del siglo pasado, el general alemán F. A. G. von Specht nos legó el Gescbichte der Waffen, nacbgewiesen und erlaulert durch die Kullurentwicklung der Völker aus allen Zeilen, I-III (Berlín-Leipzig, 1872), su grandiosa obra. En su vol. II, 1, trata el armamento de Méjico, Perú y otras culturas americanas desde el Norte hasta el Sur, hasta Patagonia y Tierra del Fuego. El científico y etnólogo sueco Erland Nordenskjöld, en unos de sus muchos libros etnográficos, también trata sobre el armamento de los indígenas, aunque no lo haga tan detalladamente como lo hizo Specht. Varios temas y categorías de armas de los aztecas, mayas e incas han sido tratados en las publicaciones del Peabody Muscum, en Harvard University, Cambridge, Mass. Pero hasta la fecha, la contribución más importante, una auténtica obra tratada a fondo, un verdadero manual sobre las armas de los conquistadores, está escrita por el argentino Alberto Mario Salas (Las armas de la conquista, 
Emecé, Editores, S. A. [Buenos Aires, 1950], 469 págs. más ilustraciones de códices y armas). Es un manual científico con exhaustivas investigaciones de las muchísimas fuentes literarias de la época, con estudios en los archivos de España y del extranjero. Gran parte se encuentra en el Archivo General de Indias y en el Museo Colombino, ambos en Sevilla; en el Archivo Histórico Nacional de Madrid; en la Biblioteca Nacional de Madrid; Palacio Real de Madrid y en otros diversos lugares españoles (Archivo del ducue de Osuna). El material consta de muchísinas cartas, relaciones, cédulas, ordenanzas, etc., escritas al emperador Carlos V por varios de los famosos conquistadores, así como por frailes como Bernardino de Sabagzin, Bartolomé de Las Casas, Diego Durán y algunos otros. Asimismo, una obra de enorme importancia es la rica fuente y gran obra del conquistador, militar y aventurero Bernal Diaz del Castillo, de Medina del Campo, escrita antes de 1556. Pero el material más importante, excepcional e interesante son las cinco larguísimas y detalladas cartas escritas por el mismo Hernán Cortés al empcrador, con todas sus relaciones, descripciones, ordenanzas, etc., así como unas extraordinarias descripciones sobre la vida diaria en Méjico, de la ciudad preciosa y limpia, de los indigenas, de los mercados, puestos, vendedores, joyeros, alimentos, sus calles, sus casas con jardines y flores, sus templos y mucho más. Hay también, de su propia mano, informes, instrucciones, cédulas, relaciones sobre armas, del modo de gobernar a los indios, crónicas, etc.; toda una descripción de la vida diaria y cultural en este país y este pueblo tan eztraño y diferente a los españoles. Gran parte está ya publicada en España. (La publicación de las cartas en 1985 está tomada del Códice de lá Biblioteca Imperial de Viena.) Otra la publicó la Universidad Autónoma y otras instituciones científicas de Méjico. El señor Salas ha tratado asimismo los famosos códices, especialmente el Códice de Mendoza (el original, en el Bodleian Library, Christchurch, en Oxford), escrito para Carlos V, pero que en su viaje a España, y a causa de la piratería, arribó a Francia, que lo vendió a Inglaterra y terminó su viaje en Oxford. Está publicado por James Cooper Clark (editor): Codex Mendoza, the Mexican Manuscript known as the "Collection Mendoza" and preserved in the Bodleian Library in Oxford (edit. y traducido por James Cooper Clark, Londres, 1938). El famoso Lienzo de Tlaxcala (actualmente muy deteriorado a causa de un incendio) también cstá tratado por Salas. Los dibujos de estos códices — con toda su sencillez- nos dan la mejor información sobre el armamento de los aztecas y españoles. Otros buenos e informativos dibujos se encuentran en la obra de Diego Durán Historia de las Indias de Nucva España, del siglo xvi, que nos muestra un armamento muy parecido al del Códice Azcutitlan de París. Con toda claridad se nota el cambio de armamento que hicieron los españoles, desde su equipo español, 
corriente a fin del siglo Xv y comienzo del Xvi (primero al armamento jinete morisco-andaluz), hasta el utilizado por los aztecas. Se ve también la milicia indígena y las tropas españolas, el cncuentro entre las dos culturas y dos milicias, y nos da alguna información sobre el arte de guerra de los incas y su organización militar en Perú.

Con su exhaustiva bibliografía y múltiples notas a continuación de todos los capítulos, es una obra indispensable para quienes desecn investigar sobre estos temas del Nuevo Mundo. Existen otras obras, parte en español, parte en inglés y alemán, algunas de ellas publicadas en Estados Unidos; la mayoría trata de épocas posteriores a la Conquista, desde comienzos del siglo xvir y más adclante, momentos en que el armamento cambió a armas europeas, bien españolas, inglesas, francesas, alemanas, bien fabricadas en el Nuevo Mundo en las fábricas que pronto surgieron allí. Ya al final del siglo XVI comenzaron a existir en Argentina fábricas de armas de fuego. Mencionaremos en este contexto un libro sobre este tema, escrito por Rafael M. Demaría: Historia de las armas de fuego en la Argentina (1530-1852), Ed. Cabargón (Buenos Aires, 1972). Con sus 380 páginas y muchas ilustraciones, puede tambićn tener interés para los que se dedican a las armas de fuego en Méjico.

Las armas de los conquistadores, es decir, las armas utilizadas en los primeros cincuenta años en Méjico (y, en cierto modo, también en Perú), tienen un interés especial por ser una extraña mezcla de dos grandes épocas españolas: el fin de la Edad Media y el comienzo de la éproca renacentista, con muchos de sus experimentos todavía en fase de estudio (armas de fuego portátiles y artillería con cañones). Las armas más importantes para Cortés - y también para Pizarro- eran las lanzas y picas, espadas grandes y tajantes (montantes, como se nota en los dibujos) y espadas de armas, más las psicológicas: los caballos y los perros, estos últimos de las razas alana, mastín y dogo. Caballos y perros constituyeron un arma completamente nueva y de sorpresa, más un horror incomprensible para los indígenas. Los caballos no habían existido en esta parte del mundo desde hacía milenios prehistóricos. Con el caballero montado semejaban los españoles algo divino, una unidad, una clase de centauro. El precio de un caballo era casi astronómico, y para Cortés fue una gran catástrofe su pérdida en «La Noche Triste» (1 de julio de 1520) (Fig. 10). Se cuidaba casi mejor a los caballos que a los soldados. Los perros, bien adiestrados, eran peligrosísimos para los indígenas. Eran extraordinarios guardianes de los campamentos, advirtiendo a los españoles de la secreta presencia nocturna de grupos de guerreros indígenas entre los bosques, así como para seguirlos ocultos entre los arbustos y árboles. Los perros de los indígenas eran de otro tipo: pequeños, silenciosos y casi mudos, pero con buena carne, que podía servir como alimento en casos extremos. Esta 
conquista, en sus principios, fue una conquista parte con auténticas armas de ataque y de defensa, parte con armas psicológicas. En segundo lugar, pero también psicológicamente importantes, tenemos las ballestas y las armas de /uego, especialmente los arcabuces de mecha, armas que Cortés, en sus cartas, llama escopetas. La ballesta desapareció después de los primeros cuarenta años. En cambio, las armas portátiles de fuego crecieron en importancia y calidad. La artillería no era aún muy significativa, aunque Cortés utilizó con éxito los cañones contra la capital, Méjico, y en algunos otros asedios. La mayoría de los cañones eran pequeños y de bronce; muy pocos eran de hierro, ya que éste, por oxidación, se estropeaba rápidamente en el clima húmedo. En sus cartas, Cortés da algunas descripciones de su artillería y su función, así como de su propia fundición de cañones de bronce. En el siglo xviI es cuando la artillería auténtica adquiere importancia; en los primeros tiempos, especialmente en Chile. El tema parece complicado, ya que se trataba de conquistar un mundo completamente diferente al conocido por los conquistadores. Aparte de ser dos grandes culturas, era un mundo heterogéneo, y el armamento dependió clel nivel de cultura y clima de las diversas regiones, de las tribus y poblaciones, desde los casi desnudos y pintados indígenas arqueros de las Antillas hasta las extraordinariamente buenas y efectivas armas de las grandes culturas de los aztecas, mayas e incas. Las representaciones que nos ofrece el arte sobre el armamento de los aztecas demuestran que no cra diferente al de sus ya conquistados y subyugados y ahora decadentes vecinos los mayas y toltecas, en aquel tiempo en Yucatán, Guatemala y Honduras. Existen diferencias entre Méjico y Perú, en cierto modo en dependencia con la diferencia en paisaje, raza, condiciones de vida y estructura de la sociedad, a pesar de que también el estado de los incas era un estado militar de alto grado.

Pasando por los reinos isleños, primitivos, de las Antillas, pero con clima favorable, alimentos frescos y buenos, llegaron los conquistadores a reinos y civilizaciones de un nivel altamente desarrollado y organizado. Ambos Estados tenían una sociedad desarrollada y organizada, con una religión dominante, un arte civil, pero también, especialmente, un arte y arquitectura militares dominantes, desarrollados a un nivel altísimo. Ambos eran Estados religioso-militares. Había escultura, pintura, artesanía de varias clases, cerámica con escenas religiosas y de guerra, orfebrería de oro y plata, piedras preciosas, mosaicos de plumas multicolores en estilo heráldico y simbólico. Su arte nos sirve hoy como fuente importantísima de conocimiento, con sus muchísimas representaciones guerreras y religiosas, con sus dioses, caudillos o caciques de varias categorías y rangos; con todo su armamento, para guerra y para ceremonias; éste, anterior o contemporáneo de la conquista. Otra fuente de no menos predicamento son 
los famosos códices, iluminados con dibujos del siglo de los conquistadores, hechos para el emperador, con representaciones de Cortés y sus compañeros, y con los aztecas ataviados con trajes característicos y su armamento típico, con las armas en la mano, como nos lo demuestran, por ejemplo, los famosos Códices de Azcatitlán (Fig. 5), en la Bibliothèque Nationale de París; con Cortés marchando contra Méjico; con las armaduras españolas de la época de Alfonso el Magnánimo y los Reyes Cátólicos; con sus rodelas, sus lanzas y sus alabardas, el Códice de Mendoza, en la Bodleian Library, en Oxford (Figs. 18-19), o el Códice de fray Bernardino de Sabagún, en Madrid, más otros códices, y especialmente el Licnzo de Tlaxcala, en Méjico (Figs. 10-11). Este último tiene unas representaciones signifícativas no sólo de Cortés con su armamento especial, sino también de sus ayudantes indígenas. En el Códice de Mendoza encontramos varios folios con explicaciones de los rangos y trajes de los cuatro grandes caudillos, con sus símbolos, honores, cascos de jaguares, ocelotes y otros (Figs. 15 y 18). El Lienzo de Tlaxcala fue hecho por indígenas unos treinta o cuarenta años después de la conquista de Méjico. Está publicado por Alfredo Chavero (Méjico, 1892).

La cultura de los aztecas -así como la de los incas- parece ser rigorísticamente dictatorial. (Hay escritores, por ejemplo, Lummis, que consideran estas culturas como una clase de democracia militar.) En ambos casos se trata de una cultura completamente militar y religiosa, con infinidad de clases y graduaciones de carácter militar-religioso, desde las más altas hasta las más bajas. La sociedad estuvo construida como una clase de clanes, capullis, unidos en cuatro categorías altas, cada una con sus autodeterminaciones. Por encima de todos estaba el superguerrero, un sacerdote-cacique con alto poder. La mayoría del pueblo la constituía los artesanos y los campesinos, más los siervos de gleba, tamemes y esclavos. Los pueblos subyugados tuvieron que alimentar y mantener a las clases altas de guerreros. Los aztecas poseían academias militares y escuelas especiales para entrenamiento en el uso de las armas. Moctezuma II tenía grandes arsenales, que contenían armas que todas clases, en sus templos y en su palacio. La adninistración de la justicia actuaba con una disciplina riourosamente militar. El dios supremo era el de la guerra, Huiızilopochili (Fig. 14), que además era el más cruel y sediento de sangre. El gran dios de los aztecas, Quctzalcóall, el creador de los hombres, a los que había enseñado a fabricar los mosaicos de plumas y de turquesas y jade, antes de su desaparición del Panteón de los Aztecas, hace ya muchos siglos, había prometido volver un día del mar del Oriente para acabar con el régimen de Moctezuma. Había sido un dios con cara blanca y pelo y barba rubios. Moctezuma creía con certeza que el hombre con rostro blanco y largas barbas que embarcó en Vera-Cruz en 1519 era el misterioso 
dios, desaparecido en el mar, pero ahora de él surgido, que ya había regresado - según su promesa- para acabar con su reino. (¿Ha sido un precoz misionero del Occidente huyendo al mar perseguido por los indígenas?) $\%$.

\section{DOS MUNDOS SEPARADOS POR MILENIOS}

El encuentro de los primeros conquistadores españoles con las grandes culturas —en este caso, Cortés en Méjico con los aztecas- no sólo fue un encuentro con dos mundos y razas completamente distintos, sino también de dos civilizaciones separadas cultural y técnicamente por milenios. Algunos científicos alemanes e ingleses han comparado estas grandes culturas de América con las de la antigua Asiria, en Mesopotamia, por su organización militar y su crueldad, o con los romanos, en la época de los emperadores militares en el antiguo Imperio romano, por su organización y sus leyes bélicas.

Los aztecas habían conquistado gran parte del actual Méjico alrededor del año 1300, quizá un poco antes. Moctczuma I, a mediados del siglo Xv, llcgó a estas regiones de los antiguos toltecas (del siglo IX hasta cerca de 1168), cuya capital era Tula. Aunque los aztecas vivían orgánica y militarmonte como los antiguos romanos, su armamento pertenecía a la época encolítica, o, mejor dicho, a la transición entre la época neolítica y encolítica. No conocían el hierro, pero habían comenzado a trabajar el cobre, entre otros usos para sus puntas de flechas y lanzas. La mayor parte de sus armas tenía aún puntas de piedra, especialmente de obsidiana, material normalmente utilizado en regiones volcánicas, al igual que, desde hace milenios, lo hacían los pueblos prehistóricos de las islas de Tera y otras del archipiélayo griego. Puntas de flcchas - sus armas más importantes- y lanzas, jabalinas y dardos, mazas afiladas, macanas, espadas y dagas, etc., eran todavía fabricadas con este material volcánico. Los aztecas salían de una época prehistórica y entraban en otro período también prehistórico.

Pero los conquistadores españoles también salían de una época cultural, la medieval baja, para entrar en la renacentista, con sus sólidas espadas de hierro y sus primeras rapieras elegantes, el futuro tipo de espadas elegantes en España (véanse las rapieras de Cortés y Pizarro en la Real Armería, G45 y G35) (Fig. 2); sus armaduras «blancas» de hierro, muchas de éstas todavía al estilo de la época de los Reyes Católicos y la Reconquista de Granada (fin del siglo xv), algunas de fabricación española

*Véase sobre la profética leyenda del dios o héroe Quetzalcóatl SaLAs, op. cit., págs. 108 y sigs. y 120 y sigs., con bibliografía. 


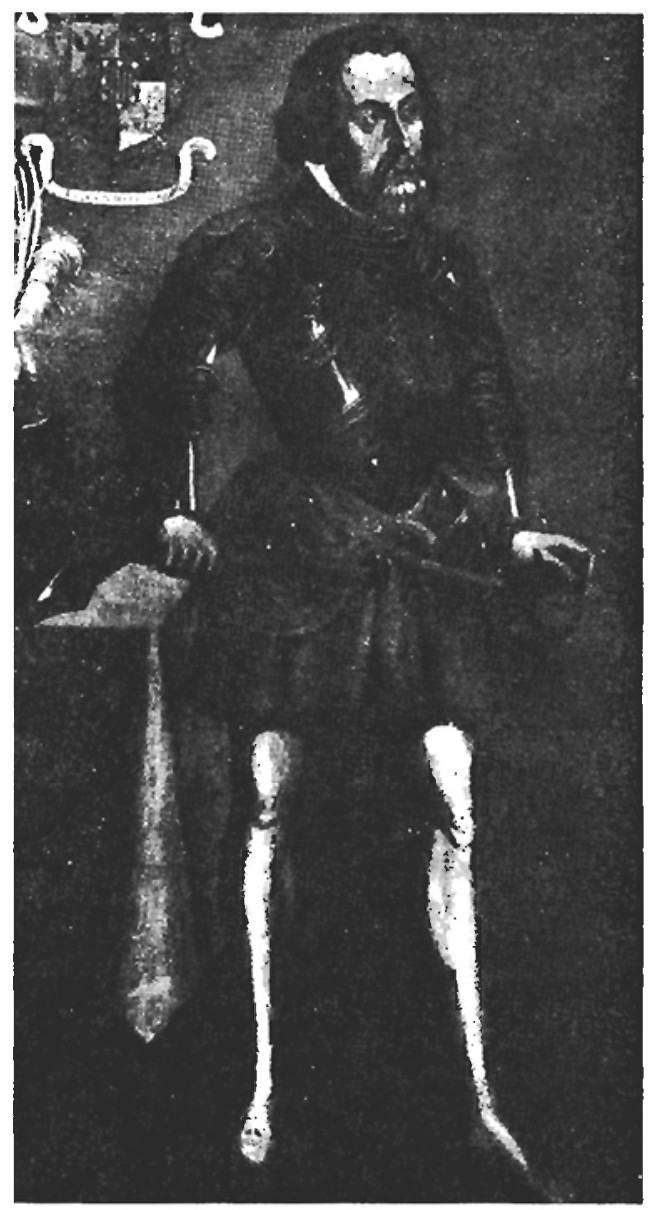

FIG. 1.- Hernán Cortés, retrato de un pintor desconocido. (Museo Hístórico, Ciudad de Méjico.)

y otras de las fábricas de Milán. Tenían ballestas excelentes, con arco de acero de Mondragón, del ripo usado en la Reconquista de Granada y por Carlos V. Pero también armas de fuego portátiles y cañones en forma de bombardas y falconetes, serpentinas y culebrinas. A pesar de estas armas en la época de transición, durante los primeros años tuvieron a veces que volver al armamento de la época medieval de los siglos XIII y XIV.

De este modo, Cortés, siguiendo los consejos del militar y colaborador Bernal Díaz del Castillo, construyó trabuquetes del mismo tipo que 
había usado Alfonso el Sabio en Castilla, en el siglo xiı, para lanzar piedras, objetos incendiarios u otra clase de proyectiles contra los muros de la ciudad de Tetelulco. Incluso armas del estilo del antiguo fuego griego de los bizantinos, e inventado ya en el siglo viI, fueron usadas por Cortés, pero según las fuentes con poco éxito. Eran granadas fabricadas con barro cocido que se llenaban con productos inflamables de varias clases, ingredientes que abundaban en Méjico.

Los españoles tuvieron que cambiar sus mejores o peores armaduras de acero, sus coseletes y cuirusses de hierro y cuero con los escaupiles de los indígenas, de canvas u otra tela, estofados con algodón, y a proteger sus caballos y hasta sus perros con escaupiles de este material como protección contra la lluvia de flechas de los aztecas y contra los dardos y tiraderas lanzadas por sus características estólicas. El escaupil, de varios tipos y tamaños, según las culturas respectivas de los aztecas, mayas e incas, fue para los españoles la mejor protección contra las armas ofensivas de los indígenas. En realidad, el escaupil no era muy diferente al gambax de canvas, cuero u otro material acolchado con algodón, usado por los caballeros medievales de los siglos xiI y xiv en la Península Ibérica y para la infantería española durante las mismas épocas.

El canvas, acolchado con algodón torcido o tratado de otra manera y bastante grosor, no permitió que las puntas de flecha penetrasen en el cuerpo de hombres y caballos, pero se quedaban en el traje acolchado.

Algunas veces la literatura moderna sobre la Conquista nos relata que Méjico fue conquistado por las ballestas, los arcabuces y los cañones. Esto, probablemente, no es correcto. No fucron las ballestas, ni tampoco las bombardas, falconetes, serpentinas o arcabuces, las que conquistaron Nueva España. Es bien conocido que estas armas fueron una estimable ayuda en algunas ocasiones, por ejemplo, para Cortés a su llegada a Tabasco y más tarde aún a Cempoala y a Tlaxcala y después en su segundo asedio a Méjico, donde representaron buen socorro colocadas en sus bergantines en el lago. Pero su efectividad era especialmente de carácter psicológico. La carencia de bestias de carga proporcionó grandes dificultades en los primeros años para el transporte de la artillería, sea de bronce, sea de hierro; también encarecía su uso la lentitud respecto a preparar, limpiar, cargar, apuntar y disparar estas armas. Los primeros años en este país, con sus difíciles terrenos, y probablemente los primeros cuarenta años de la Conquista, fueron hechos por medios psicológicos; los caballos, perros (cspecialmente contra los mayas y los incas), ruido, olor de las armas de fuego, combinado todo con una táctica inteligente y bien planificada por Cortés, fue lo que conquístó a los indígenas. Los cañones y los arcabuces recordaban a los indígenas sus volcanes en erupción y consiguieron que se intimidaran. Las armas más peligrosas para los indígenas eran la espa- 


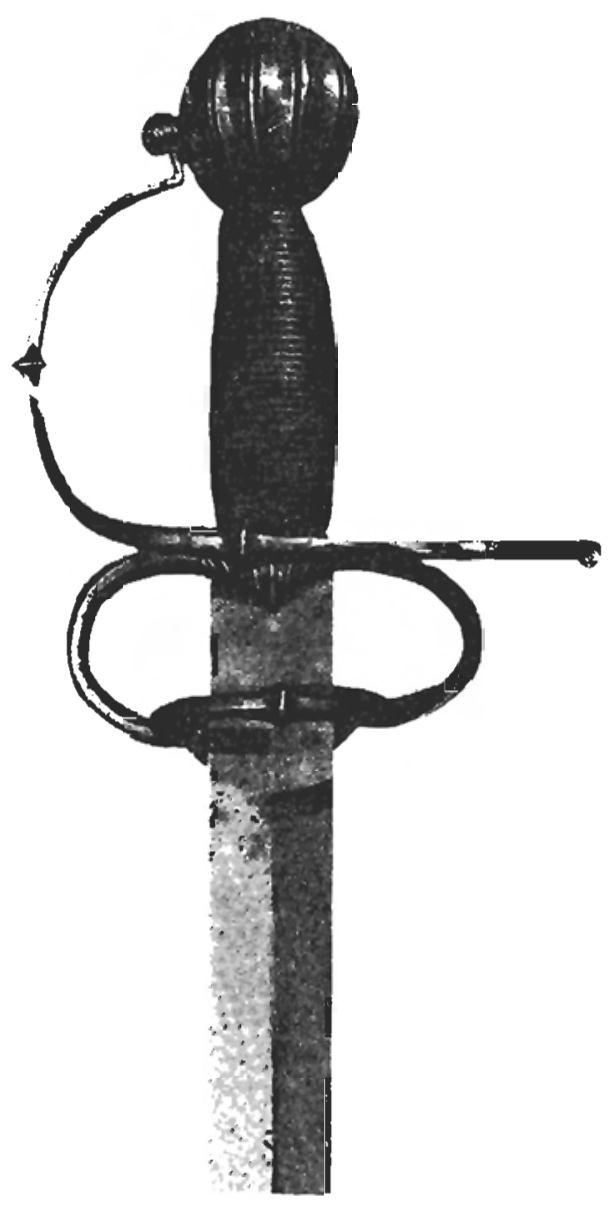

Fig. 2a.-Espada de Hernán Cortés, usada por él durante sus años en Méjico (Real Armería, G45, Madrid). En la hoja, la marca de un perriIlo y restos de una inscripción indescifrable. De hierro acerado. Largo: $1,01.0 \mathrm{~m}$.; ancho: 0,032 metros. 


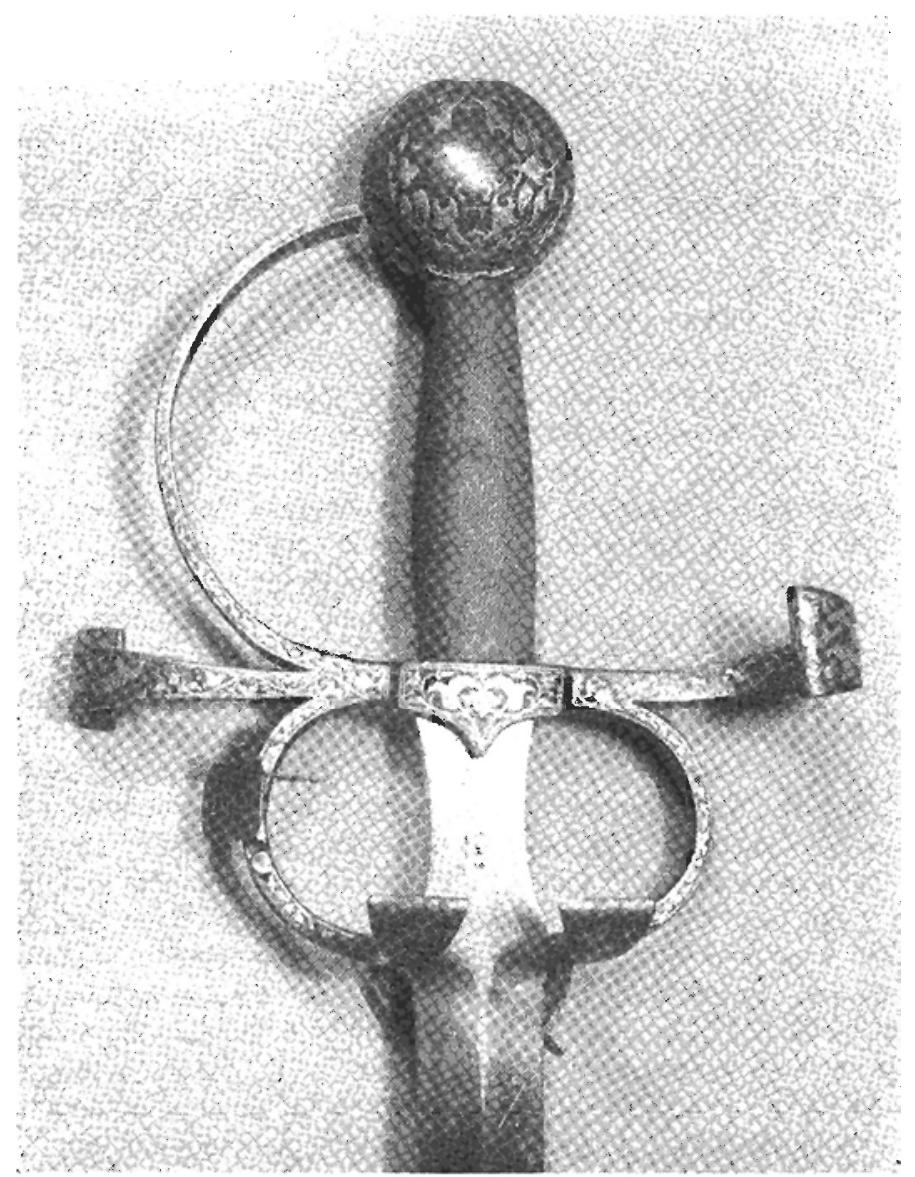

Fig. 2b.-Espada de Francisco Pizarro, conquistador de Perú en 1536, probablemente hecha hacia $1520-1530$, con ataujía toledana, pero en estilo florentino, en oro y plata. La hoja es del espadero valenciano Mateo Duarte. Largo: $83 \mathrm{~cm} .:$ ancho: $2,7 \mathrm{~cm}$. (Real Armería, G35, Madrid). (¿Regalo de Carlos V?) 
da, la lanza larga andaluza-morisca de los jinetes y las ballestas. A esto añadió Cortés: «¡No teníamos, después de Dios, otra seguridad sino la de los caballos!»

\section{LAS ARMAS DE LOS ESPAÑOLES}

Cortés llegó el año 1519, desde sus fincas en Cuba, a las costas de Méjico, a Tabasco —o mejor dicho, Yucatán-, a un lugar que después fue llamado Villa Rica de Vera-Cruz. Aquí fundaría la ciudad de este nombre. Tenía entonces, según la mayoría de las informaciones literarias, II naves, 553 soldados, 110 marineros, 200 indios de las Antillas, 82 ballesteros y 13 arcabuceros, más algunos piqueneros de a pie. Traía consigo también 16 caballos con sus jinetes, más diez cañones pesados de bronce y cuatro de tipo ligero, de falconetes. Toda esta artillería fue bautizada por los cronistas e incluso por Cortés como «tiros» para mayor comodidad, debido a la gran confusión respecto a la terminología. Un año después le traía Narváez con sus naves, enviadas desde Cuba por Diego Velázquez, después de su fracaso rebelde frente a Cortés, 800 infantes, 80 jinetes con sus caballos, 80 mosqueteros (probablemente arcabuceros), 120 ballesteros y 12 cañones de varios tipos. Algunas veces el número de sus hombres se aumentó, más o menos casualmente, pero nunca fue un ejército grande. El año siguiente al sitio de Méjico tuvo que comenzar con un total de 12 naves, 818 hombres europeos de infantería (en ese número estaban incluidos 118 ballesteros y arcabuceros), más tres grandes cañones para campaña y 15 cañones de tipo ligero. Con este ejército tan pequeño y tan variado, y con las enormes dificultades de transporte, llevaba a cabo Cortés sus brillantes hazañas. Pero un elemento fundamental en esta procza era su propia inteligencia, su astucia tan eminente y su diplomacia, utilizando la rivalidad que dominaba entre las varias ciudades mejicanas, más la animosidad general contra la dictadura azteca. Gran ayuda tuvo Cortćs por parte de la ciudad o, mcjor dicho, Estado libre de Illaxcala, ya conquistado y enemigo hereditario de Tenocbtitlán, la posterior ciudad de Méjico.

Los conquistadores llegaron a Méjico con las mismas armas que se usaban en la Península y que antes se habían utilizado en las guerras de Italia bajo el Gran Capitán, Gonzalo de Córdoba, es decir, armamento de la época de los Reyes Católicos en sus guerras y última reconquista de Granada, de fines del siglo xv y comienzos del xVI. Representaciones de los españoles en algunos de los famosos códices, entre ellos el Códice de Azcatitlán, en la Bibliothèque Nationale de París; el Códice de Mendoza y el Lienzo de Tlaxcala (Figs. 3-5), así como en otros varios, nos 


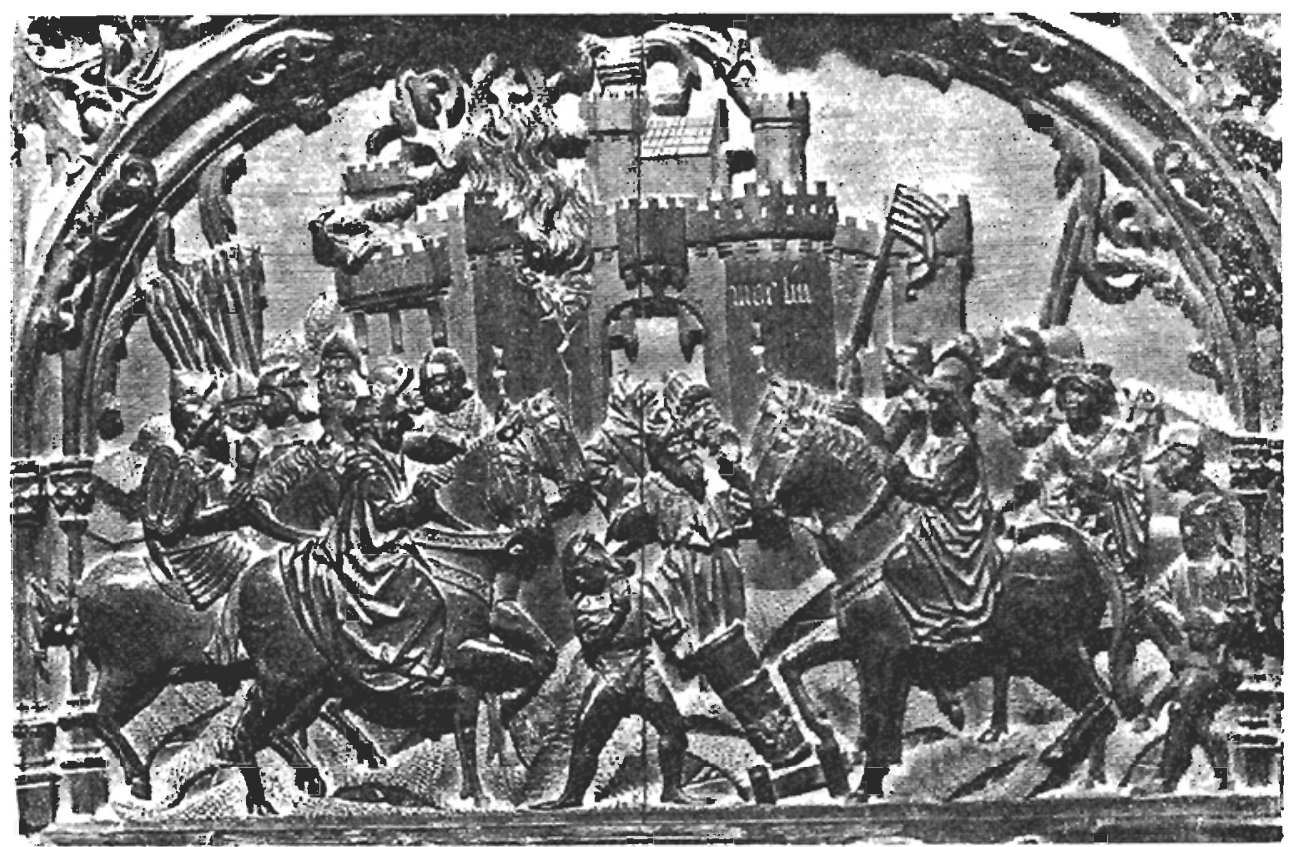

Fic. 3.- Tallas en relieve del coro de la catedral de Toledo, de 1495-1500 aproximadamente, por el maestro alemán Rodríguez. Tropas castellanas conquistan Moclín. La torre arde por efecto de las bombardas. Un armamento parecido a éste era, en general, el utilizado por los ejércitos de Cortés en Méjico. Nótese la bombarda enfrente, las armaduras, cascos, escudo de tipo adarga y las lanzas.

ofrecen información sobre armaduras (armaduras blancas) de acero y hierro, como se ve en los relieves del Arco de Triunfo de Alfonso el Magnánimo en Nápoles, en las preciosas tallas de las catedrales de Toledo y Granada o en un tablero de la sillería del monasterio del Parral, en Segovia, hoy en el Museo Arqueológico Nacional, en Madrid, anterior a 1526 (Figs. 3-4), los dos primeros representando la Reconquista de Granada.

Los tipos no difieren de los representados en el arte pictórico de la misma época o de las armas auténticas expuestas en la Real Armería de Madrid. Hay representaciones de cascos con gorgera y baviera correspondicntes a una de las celadas históricas (A16) en la Real Armería, perteneciente a Felipe el Hermoso, y en el Códice de París (Fig. 5). Este armamento tiene también sus paralelos en el Waffengeschichtliches Museum, 


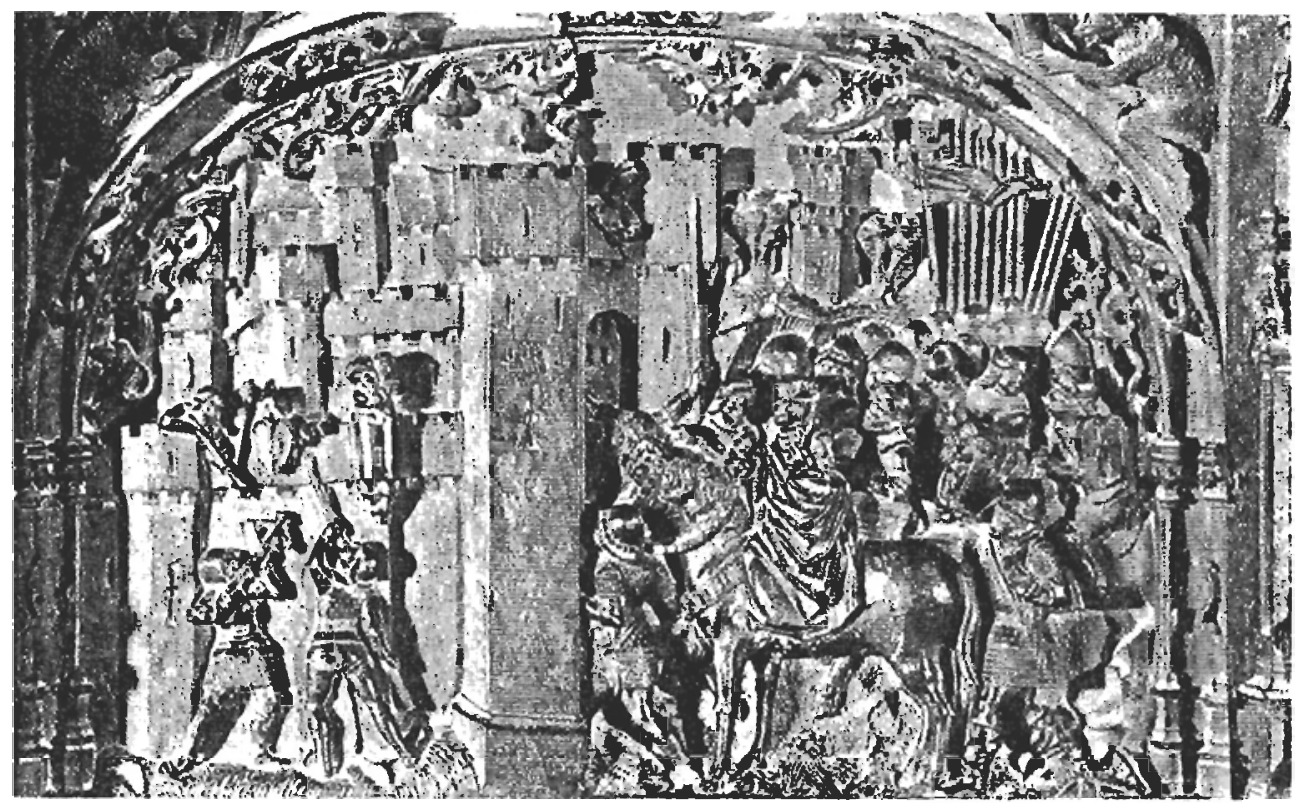

Fig. 4.-Atayue y ocupación de Gor en 1489. Sillerías del coro de la catedral de 'Toledo. Nótese al aimamento de los gucrreros: armaduras, capacetes, más ballesta y arcabuz.

en Viena (la armadura de campaña del rey Fernando el Católico, aproximadamente de 1495, y un peto de Felipe el Hermoso), o en otros museos europxos, así como en el Museo Metropolitano de Nueva York; en parte era cspañol y en parte de fabricación y estilo milanés. Eran armaduras más o menos completas, todas de metal. En estos códices, por ejemplo, el de París, podemos ver los mismos tipos de petos y láminas de faldas, hombros, brazales, cuisses y piernas, y hasta de cuando en cuando los sabatones. Hay guerreros con cascos cerrados, con la visera baja, y se notan también capacetes, celadas y morriones. En una fuente literaria de la época se menciona que los pocos portugueses que participaron en esta conquista pescían mejor armamento que los españoles. Esto, posiblemente, sea difícil de comprobar. El llamado «Hidalgo de Elvas», un portugués, en su descripción de la expedición de Hernando de Soto a Florida, en 1528, habla del miserable armamento de los españoles de Cortés y de los otros conquistadores (véase The Narrative of the Expedition of Hernando de Soto, by the "Gentleman of Elvas», en Spanish Explorers in the 


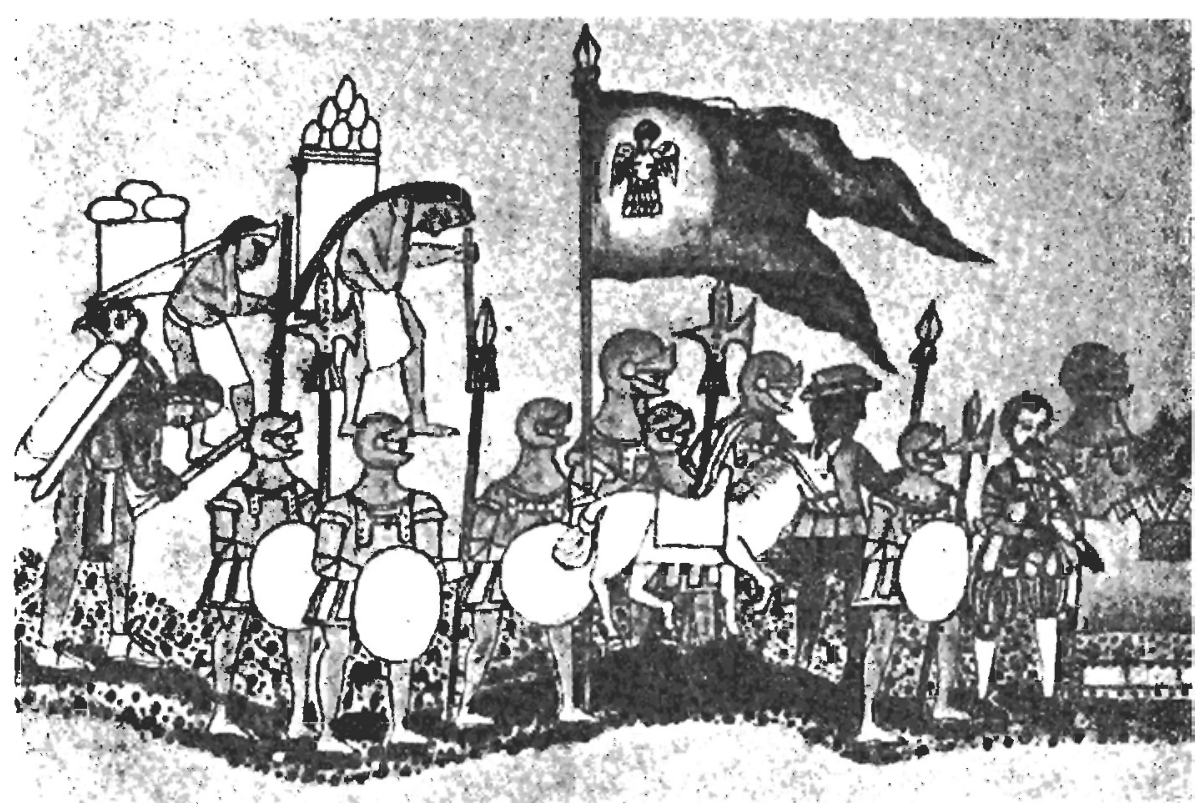

Fig. 5.-Cortés con su ejército marcha contra Méjico. Los guerreros españoles están vestidos con armaduras de hicrro, con sus bacincres con visera movible y levantada, con lanzas y alabardas. Tamemes indigenas uaen armanento; por cjemplo, un arcabuz (Códice Azcatitlán, Bibliothèque Nationale de París).

Soutbern Uniled States, 1528-1543, Nueva York, 1907). Existe un testimonio del armamento de los portugueses de finales del siglo xv en los preciosos tapices de la iglesia colegiata de Capestrana (Guadalajara). Estos tapices repiesentan, entre otras escenas, al rey portugués Alyonso $V$, el Africano, y su hijo con guerreros en plena batalla en la conquista de Arcila, en Marruecos, en el año 1471. Todo el armamento portugués está aquí representado detallada y correctamente. Hay capacetes y morriones del tipo usado en España a finales del siglo xv y comienzos del xvi. Hay armaduras completas de la época, cotas de malla, brigandinas forradas con terciopelo carmesí, adargas, lanzas, espadas de la época y hasta arcabuces del tipo usado por Cortés y sus arcabuceros. Tienen también una excelente representación de la artillería de la época. Todo el armamento es similar al de los Reyes Católicos en las tallas de Toledo. Todo parece ser correcto y de buena calidad. Estos tapices están ejecutados poco después de la conquista de Arcila, probablemente entre 1475 y 1480 , según dibu- 
jos del pintor portugués Nuño Gonçalves, por tejedores flamencos. Probablemente son obsequios del rey portugués Juan II a la familia del duque del Infantado, el cardenal Pedro González de Mendoza, y por este cardenal regalados a la Colegiata de Pastrana. Los tapices están reproducidos, entre otros, por Reynaldo Dos Santos, Tapeçarias da Tomada da Arzila, Lisboa, 1925, y mencionados y asimismo reproducidos por Jorge Vigón, Historia de la artillería española, 1, Madrid, 1947, más en el catálogo Carlos $V$ y su ambiente, exposición homenaje en el cuarto centenario de su muerte (1558-1958), Toledo, 1958, con una lista bibliográfica. Una buena representación se encuentra también en James Mann, en su artículo sobre Spanish Arms and Armours, en «A rqueología», Oxford, tomo LXXXVIII, 1933. pág. 294. Lo cierto es que sólo algunos de los conquistadores de Cortés lucían armaduras completas. Habían guerreros con media armadura, con cuisses hasta las rodillas, con cascos abiertos, morriones, celadas, cervelleras, etc., pero muchos tenían solamente petos de hierro con dorso o petos solos. Algunos de los caballeros tenían también armaduras ecuestres de hierro con testeras, pecheras, flanqueras, groperas; otros no poscían otra clase de defensa para sus cabalios que faldas y capuchas de cuero crudo. Sus sillas eran del tipo pesado de Castilla. Al lado del armamento de buena calidad existía también el anticuado y hasta lorigas medievales, que — según dicen algunas fuentes de la época- eran una buena protección contra las flechas de los indígenas, especialmente debajo de un escaupil de algodón. Las lorigas de malla muy fina $y$ de tipo especial que algunos españoles usaban en las Antillas no podían resistir a las fuertes flechas de los isleños. Las lorigas medievales probablemente han sido corrientes. Los infantes comunes solamente tenían coseletes de hierro, en forma de peto, con o sin dorso, todo de hierro y de color negro. Sus cascos eran de varios tipos, en forma de capacetes o morriones. No faltaban las cervelleras medievales (del estilo de Calatalyud). Algunos de los ballesteros lucían brigandinas, probablemente de fabricación aragonesa y valenciana o de Milán, que tenía fama especial en la fabricación de estas armas defensivas (Fig. 6). El tipo de ballesteros está bien representado en la Real Armería, con todo su equipo de armas. Los arcabuceros iban vestidos de manera similar a como lo hacían los ballesteros y alabarderos, algunos con petos de hierro, con una protección más o menos completa para brazos, y con cuisses.

Los escudos que llevaron al Nuevo Mundo eran antiguos, de madera, forrados con cuero, o de metal, generalmente una especie de rodela, demasiado pesados y poco manejables, en especial para movimientos rápidos que protegieran las piernas y pecho de los caballos. Había también otro tipo de rodelas, pequeñas, de unos $50-60 \mathrm{~cm}$. de diámetro, hechas de placas de madera y con un marco de metal, casi broqueles. Eran más li- 
Fic. 6.-Guerrero de la infantería española, con capacete, bavicra, loriga de malla y brigandina. Los brazos y piemas, protegidos de hierro (Real $\Lambda \mathrm{r}$ mería, Madrid). E, mismo tipo de vestido fue usado por los ballesteros de Cortés.

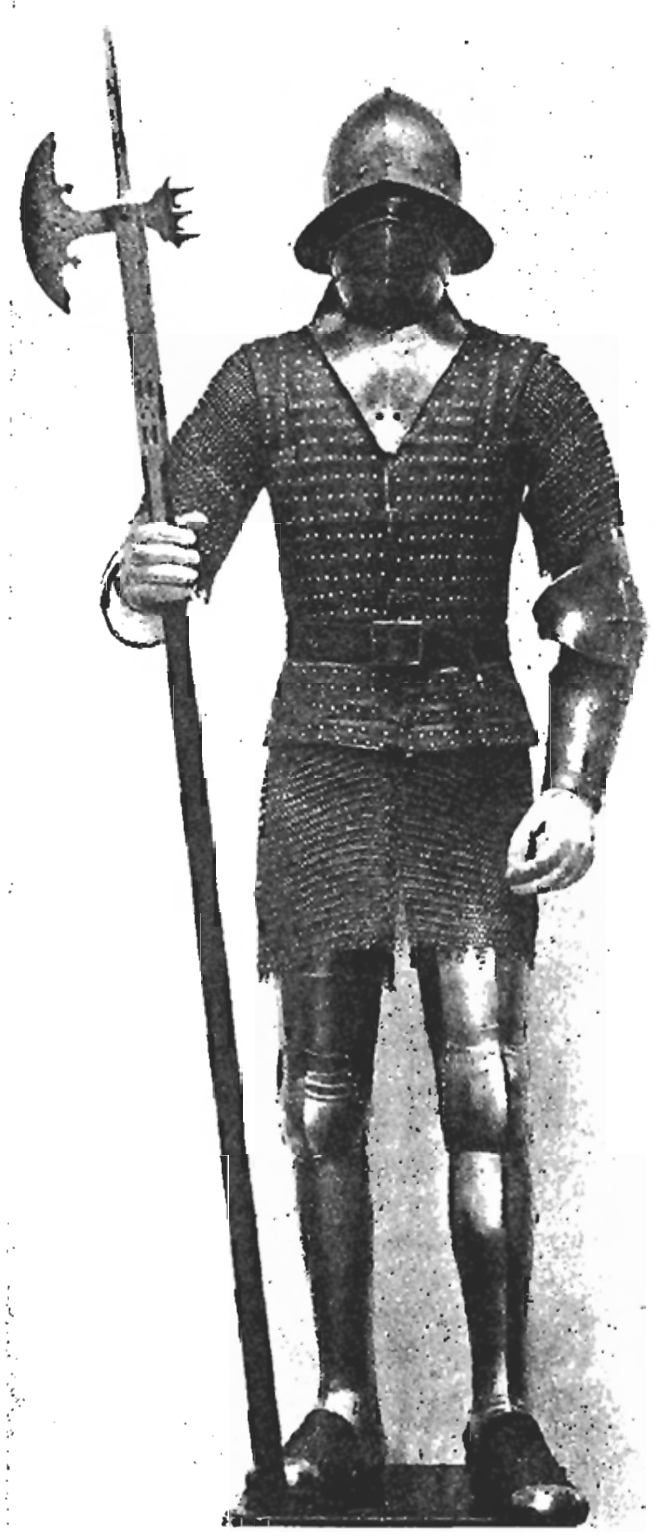


geras y más manejables. En algunos casos las rodelas eran de corcho, que resultaban una buena protección contra las flechas de los aztecas. Las flechas no podían penetrar, pero quedaban vibrando en el escudo. Estas rodelas las utilizaban especialmente los infantes. Los jinetes tuvieron que cambiar sus escudos normales por las adargas hispano-moriscas. Lo mismo ocurrió con las demás armas, especialmente con las lanzas. La lanza grande para caballería, que necesitaba ristre en el peto de la armadura, fue cambiada por el tipo ligero de los jinetes hispano-moriscos de Andalucía. Además fue necesario el cambio de las sillas corrientes y pesadas por las sillas andaluzas con estribos cortos, a fin de forzar su cabalgada en los bosques y también en las llanuras del país. El equipo del jinete andaluz era más apto para la lucha contra los guerreros aztecas. El cambio al estilo morisco, y especialmente el de los escudos por las adargas de cuero de tipo morisco, explica por qué este típo de armamento con las adargas son casi los únicos escudos que se ven en las ilustraciones mejicanas. También se explica el motivo por el que los mejicanos regalaran a Carlos $\mathrm{V}$ y Felipe II las preciosas adargas de plumas, que hoy se pueden ver en la Real Armería de Madrid (D 88) y en Viena. Las adargas que utilizaron los conquistadores en la época de Cortés todavía eran —en gran parte- de Córdoba, que desde la época de los moros había tenido fama por este tipo de armamento, una clase de artesanía que posteriormente fue trasladada a Marruecos, probablemente a Fez.

Todo este armamento, de acero y hicrro, tuvo que ser revisado y cambiado por los conquistadores por razones climáticas, por su peso y por el transporte en terrenos tan difíciles como los mejicanos y peruanos. El sol y el calor húmedo abrasaban a los conquistadores, encerrados en esta especie de «hornos» de hierro. Los cascos de hierro quemaban las cabezas, y las láminas de hierro en los hombros de la armadura les produjeron heridas y quemaduras dolorosas. Los caballos sufrieron bajo el peso de sus láminas y groperas de hierro y de las pesadas sillas. Sus testeras eran molestas, aunque en algunos casos era necesario proteger sus cabezas con estos yelmos de metal. Además, toda esta pesadilla de hierro caliente hizo que los caballos se quedaran inmóviles en los bosques y en las grandes llanuras desérticas. Por razones de quemaduras e inmovilidad fue imposible defenderlos contra la lluvia de flechas lanzadas por los indígenas. Pronto aprendieron los conquistadores a cambiar estos «hornos» defensivos por los vestidos ligeros y efectivos de los aztecas. Los escaupiles eran livianos si los comparamos con las armaduras de hierro, eran más airosos y adcmás más baratos. Las flechas se quedaban en el grosor de canvas y algodón, sin llegar al cuerpo y sin dejar heridas, al menos heridas de importancia. Los caballos fueron cubiertos con escaupiles, y para proteger su pecho y sus piernas les pusieron faldas de cuero crudo con muchos 
pliegues. Un arma que resultó efectiva contra los indígenas era la pica larga de los infanles, que en las guerras europeas de la época había resultado eficaz (Suiza, Italia). Los infantes también usaban alabardas, llamadas «murciélagos» por los indígenas debido a la forma de sus hierros; pero parece que eran de poca importancia (Fig. 6).

Las armas más temidas de los indios en las primeras épocas eran las ballestas y las armas de fuego. En principio les despertaron su curiosidad, pero pronto, especialmente, su horror. Los arcabuces eran para ellos un arma terrorífica. Estas armas no tuvieron gran utilidad debido a su peso y a las maniobras complicadas para su uso, ya que resultaban demasiado lentas en una defensa o en un ataque o emboscada contra los indígenas.

La ballesta desempeñó un gran papel al principio por ser una cosa nueva, completamente desconocida e interesantísima (Fig. 7). Pero pronto los indígenas aprendieron a defenderse contra las saetas y cuadrillos de esta arma, entre otras cosas con unos paveses especiales.

En su función, la ballesta era demasiado lenta. Para competir con la lluvia de flechas de los indígenas eran necesarias por lo menos dos personas, y mejor tres, para atenderla, para la tensión, poner los aparatos necesarios en forma de cranequins, armatostes o alounas veces también la antigua gafa o «pie de cabra». El ballestero disparaba solamente una saeta o cuadrilla en el mismo tiempo que un indígena empleaba en disparar ocho o diez y hasta doce flechas. Además era bastante difícil hacer puntería, ya que los aztecas, en sus ataques, bailaban, saltaban y bamboleaban en movimientos rápidos; así que era imposible fijar el punto de mira contra ellos. Los españoles tuvieron que trabajar en una clase de teamwork. Un guerrero preparaba la tensión de la ballesta, otro el proyectil y otras personas aparejaban las ballestas sucesivas para poder lanzar un disparo tras otro contra el enemigo. Era necesario en todo momento tener una o dos ballestas listas para un nuevo tiro. Las ballestas que usaban los conquistadores se pueden ver en la Real Armería, Museo del Ejército y otros museos. Generalmente eran de buena calidad, con arco de acero de Mondragón, en Guipúzcoa, y sin ornamentación ninguna. Existían también tipos con arcos de cuerno. Otros ejemplares exa lujosos, con intarsia, ataujía, etc., pero lógicamente no eran corrientes. Existen colecciones particulares en Méjico y otros países americanos que poseen ballestas de este tipo, originarias de los conquistadores. Como arma de guerra todavía estuvo la ballesta en su cenit; el tipo se conoce muy bien por las representaciones de relieves de finales del siglo $x V$ y comienzos del XVI, entre otros en el anterior mencionado Arco de Triunfo en Nápoles, el relieve de un claustro en la catedral de Barcelona y en las tallas de Toledo y Granada. El mismo emperador Carlos V tenía ballestas de este tipo, pero para caza, como se puede ver en su armería en Madrid. Su defecto en las luchas 
en Méjico era su lentitud en la preparación, posibles fallos, mala suerte si una nuez saltó de su hueco en la cureña o si se rompió la cuerda. Entonces el ballestero no podía continuar. Parece que la ballesta sólo tuvo importancia en los primeros cuarenta años. Poco a poco desapareció del armamento, y en el siglo xvir ya no se veía en los ejércitos.

Cuando Pizarro, en 1524, salió de Panamá con dirección a Perú, llevaba consigo gran número de ballesteros, pero para la conquista de este país, en 1536, el número de éstos había disminuido considerablemente.

En Europa, las armas de fuego aparecen en el siglo XIv y se desarrollan y mejoran durante el xv; se generalizan en el Xvi y modifican por completo y fundamentalmente el arte militar. La ballesta fue considerada en los primeros años como arma innoble, lo mismo que sucedió con la de fuego portátil. El noble caballero guerrero de la época medieval desapareció. Lo sustituyó el guerrero militar, el lansquenete, el soldado, el futu-

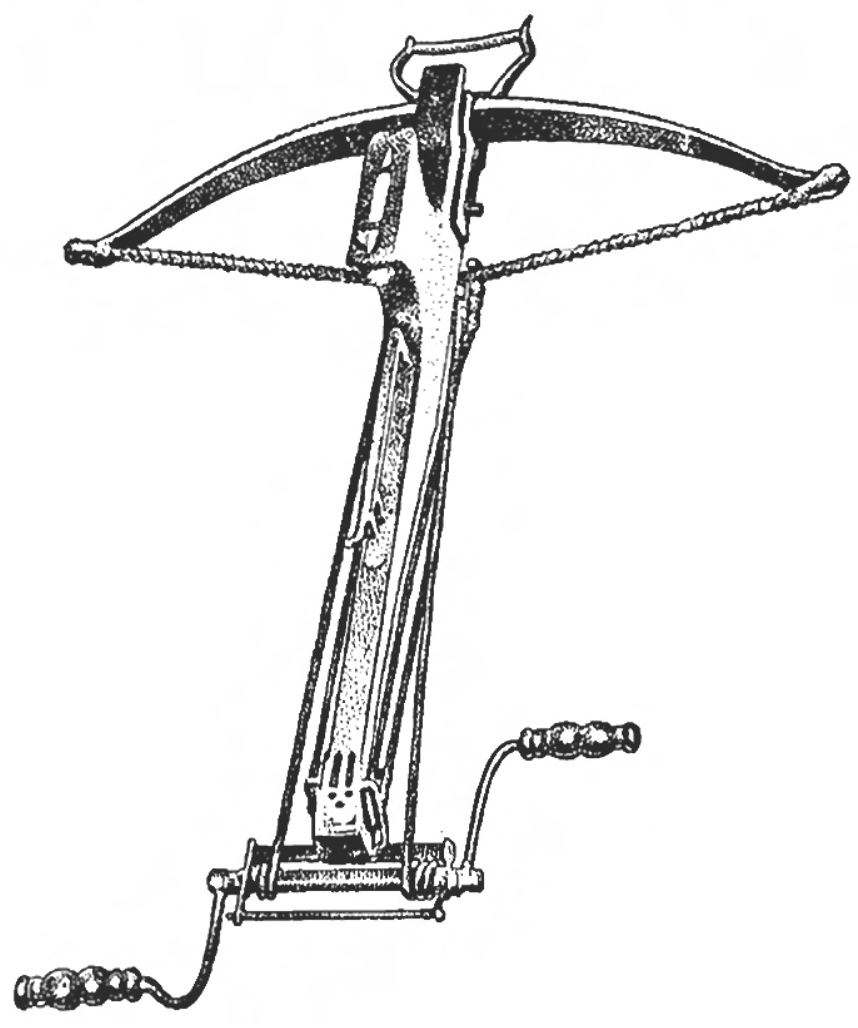


ro hombre de guerra. Las armas de fuego, de todas formas, no tuvieron gran importancia militar y no contribuyeron mucho a la conquista; sin embargo, sí la tuvieron como instrumento psicológico. Así, estas armas, en las primeras épocas, producían en los indígenas una sorpresa enorme, casi divina, un terror grande por su llama, su detonación, su olor y su humo. Además causaron heridas hasta entonces desconocidas por ellos. Procuraban la muerte instantáneamente o con rapidez. Los embajadores de Mcctezuma, en sus relatos al jefe azteca, le refirieron los horrores que presenciaron.

Pero el proceso para preparar las armas de fuego, sean portátiles, sean cañones en sus varios tipos y ramaños, limpiar, hechar pólvora, pelota, cebar la cazoleta con pólvora, tomar posición, ignición con la mecha empapada de salitre y otras materias, necesitaba tiempo y paciencia. Durante tcdo este ejercicio cayeron las flechas de los indígenas a torrentes. Bas-

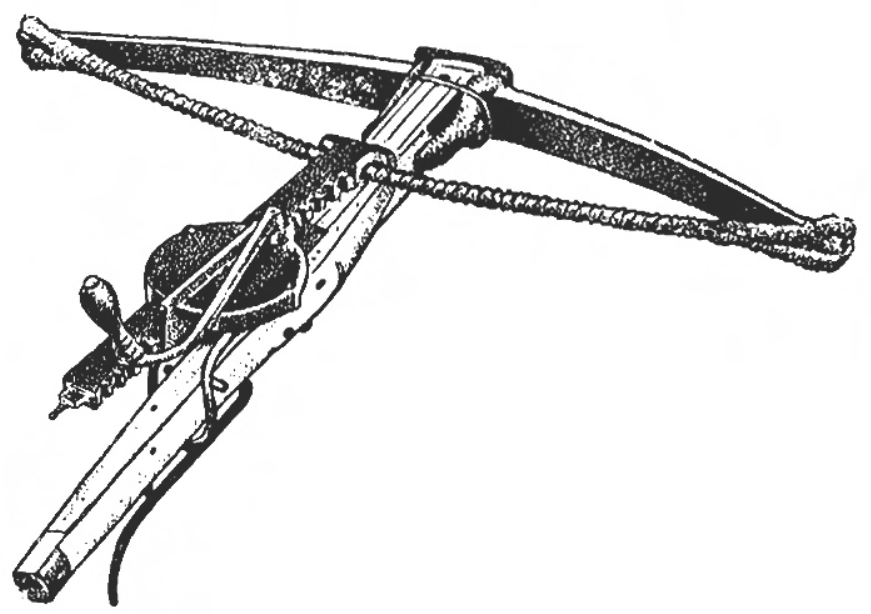

FiG. 7.-Ballestas de armatoste y de cranequín, de los tipos usados por los ballesteros de Cortés. Había también tipos más sencillos y con «pie de cabra» (Colección particulat, Argentina). 
tante más tarde, ya con la llave de rueda, con su sistema de ignición por un trozo de pirita para producir la chispa, las maniobras se mejoraron. La llave de rastrillo no aparece en Hispanoamérica antes de 1630, después de las grandes batallas americanas. Respecto al armamento con armas de fuego, los accesorios y los pertrechos necesarios que poseían los conquis. tadores no eran de alta calidad ni tampoco de última moda. Así, el mismo Colón, en su segundo viaje, en 1493, trajo en total unas cien de las llamadas espingardas, armas imperfectas y poco prácticas. Según Jorge Vigón, se parecian a las llamadas culebrinas de mano, documentadas desde 1449 en T'oledo, pero ya fuera de uso en la Península. En el Museo del Ejército de Madrid se expone la caña de una culebrina de mano (número 1.926 ), usada por Cortés (según las fuentes) en la fortificación de $S e$ gura de la Frontera en 1519, a su llegada a Méjico. Es de hierro forjado y de $16 \mathrm{~mm}$. de calibre, $96 \mathrm{~cm}$. de largo y pesa $7,59 \mathrm{~kg}$. Tiene una espiga de $31,3 \mathrm{~cm}$. en la boca y otra menor en la culata. Existen en el mismo Museo alyunas culebrinas más, de mayor calibre (29 y $31 \mathrm{~mm}$.), que fueron utilizadas por los valencianos en la guerra de Carlos $V$ en Alemania, en 1520-1521. Las culebrinas de mano fueron pronto sustituidas por las Ilamadas escopetcis a fines del siglo xv y comienzos del Xvi. Cortés en sus cartas al emperador y Díaz del Castillo en su Historia verdadera hablan mucho de las escopetas, que se utilizaron, junto a los arcabuces, al final de la conquista de Méjico, en 1521. Es posible que las escopetas no hayan sido tan corrientes como los arcabuces, pero en las dos fuentes principales, así como en otras literarias de la época, se lee con frecuencia la denominación de escopeta, sin ninguna explicación (Figs. 9-10). En Europa occidental, como en la misma Península, ya estaban pasadas y se las sustituyó por los arcabuces de mecha, de tipos parecidos a las representaciones de Dicbold Schillings Bernerchronik, de 1480, y los más desarrollados de Die Zeugcbïcher des Kaisers Maximilian de Austria, alrededor de 1514, y El triunfo de Maximiliano, publicado en 1526. Los conquistadores, con frecuencia, recortaron las cañas de sus arcabuces para hacerlos más cómodos, más «secretos»: un arma para el asesinato. Algunos de los tipos de arcabuz de los conquistadores se encontraban todavía en uso en los primeros años del siglo Xvir. El arcabucero tuvo que traerse todos los posibles accesorios: su talabarte, frascos de pólvora, polvorín, más un cebador para cargar la cazoleta, etc. La larga mecha se la enrollaba en su cinturón, en su brazo o en la misma mano. Los conquistadores no poseyeron portamechas hasta bastante más tarde. Su peor enemigo era la lluvia. Entre sus otros accesorios había también una bolsa de cuero con pelotas, plomo, molde para fundir nuevas pelotas, si es que el arcabucero tenía material y posibilidad para hacerlas. Con todas las maniobras precisas para que funcionasen y con los detalles de las herramientas y per- 
trechos necesarios está claro que estas armas resultaban demasiado lentas e inestables.

Además, para conseguir aumentar o mejorar sus provisiones hubiesen necesitado que las comunicaciones con España no fuesen tan largas y lentas y la economía de los conquistadores tan precaria.

Es casi seguro que el mosquete no fue utilizado en los primeros años de la conquista. Tenía mayor callibre y peso que el arcabuz, por lo que precisaba de horquilla como soporte para apuntar y disparar; también una función demasiado lenta. Normalmente pertenece al siglo xviI. Pero ya en 1521, en las guerras de Carlos V en Italia, se conocía su uso, como se puede ver en representaciones de la Entrada del emperador en Bolonia (de 1530).

Cuando apareció esta arma por primera vez (hacia 1540) en Nueva España, era como artillería menor, para asedios de fortalezas y ciudades, donde no había demasiados problemas con el transporte.

La arlillería con cañones fue usada en varias ocasiones. Las crónicas y otras fuentes literarias hablan de artillería con cañones, llamados «tiros», sin definición respecto a tipos o tamaños. Aunque existía artillería de varios tipos y categorías de cañones, no ha sido tan corriente como generalmente se ha dicho en la literatura moderna. Una de las razones era el transporte difícil. No había otra forma para ello que los pobres tamemes.

Este transporte de cañones por medio de tamemes se ve con toda claridad en las ilustraciones de Diego Durán, del siglo xvi, y en el Lienzo de Tlaxcala. Los terrenos a pasar eran difíciles, algunas veces con grandes bosques y otras no transitables a causa de ríos y lagos. Otra dificultad era el riesgo de emboscadas tendidas por los indígenas. Hubo ocasiones en que fue necesario abandonar en el camino los cañones más pesados por las diversas dificultades que encontraron los conquistadores en su marcha. Según Díaz del Castillo, Cortés necesitaba más de mil indígenas para el transporte de su artillería desde Tlaxcala hasta Méjico. El cronista hace una descripción detallada de la manera primitiva, casi «faraónica», para transportar estos cañones en unos terrenos tan poco transitables. Fuc una operación lenta. Las piezas de «tiros» normalmente eran pequeñas. Las denominaciones que más se dan en la literatura son: pasavolantes, falconetes, versos y culebrinas, aunque también se ofrecen otros nombres. Hay un gran número de nombres y apodos, difíciles de clasificar. El material era el «metal», es decir, bronce; pero también se dan indicaciones sobre los cañones de hierro.

Cortés, de cuando en cuando, menciona en sus cartas la artillería; es lo que sucede también con Díaz del Castillo en su Historia verdadera. En su tercera carta al emperador, en mayo de 1522 , Cortés habla de su artillería frente a Tlaxcala, donde tuvo ochenta ballesteros y escopeteros, más 


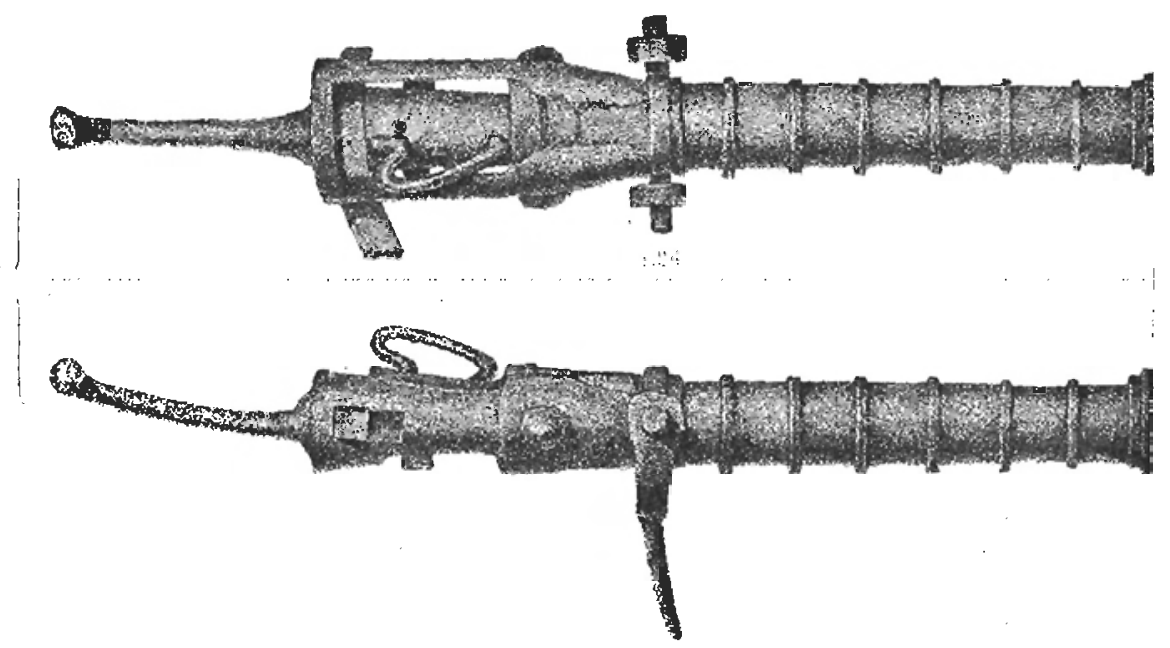

Frg. 8.-Falconete (fín del siglo xv) del tipo usado por Cortés y mencionado varias veces en sus cartas al emperador Carlos V. Calibre: $5,10 \mathrm{~cm}$.; longitud: $72 \mathrm{~cm}$. Hierro forjado (Museo del Ejército, Madrid, n. 997).

ocho o nueve «tiros» de campo. En la cuarta carta, de octubre de 1524 , habla de los «tiros» que le han traído los navíos. Un grupo era de cañones, todos de metal, pequeños y grandes, de tipo falconete (Fig. 8). De hierro eran algunas lombardas, pasavolantes, versos y otras «maneras de tiros». Cortés dice en su cuarta carta al emperador, al terminar su campaña en Méjico, que poseía las siguientes piezas, algunas fundidas en «esta tierra»: «He hecho y hago cada día algunas piezas, las dos medias culebrinas y las dos poco menos en medidas y un cañón serpentino y dos sacres, que yo traje cuando vine a estas partes, y otra media culebrina, que compré de los bienes del adelantado Juan Ponce de León. De los navíos que han venido, tendré por todas de metal, piezas chicas y grandes, de falconete arriba, treinta $y$ cinco piezas, y de hierro, entre lombardas y pasavolantes y versos y otras maneras de hierro colado hasta setenta piezas.» La artillería de Cortés parece muchas veces algo casual. Hay varios tipos y tamaños, la mayor parte de los tipos bien conocidos a finales del siglo xv y comienzos del xvi. Predominan las bombardas y los falconetes, los últimos probablemente por ser ligeros y transportables. Los versos parecen ser una variedad de los falconetes. En el Lienzo de Tlaxcala y en los dibu- 
jos de Diego Durán se encuentran algunas veces cañones montados en cureñas de ruedas, apreciándose también unas bombardas trabuqueras con «mantas» de madera, que ya en la Península se habian convertido en morteros o pedreros.

Si comparamos la artillería de Cortés con las representaciones de la ya mencionada muestra del armamento en los tapices de Pastrana, que muestran la conquista de Alfonso $\mathrm{V}$, el Africano, esta vez de Tánger, en 1471 , es notable que la de los portugueses es mejor y más variada: bombardas montadas en bancos y protegidas por sus «mantas» izables de madera, más bombardas gemelas, etc. Al margen de todas las dificultades que tenía Cortés en relación con su artillería, aún había otra: la escasez de quien supiese utilizarla. La pérdida de expertos y su sustitución por soldados corrientes sólo dieron problemas. Las hazañas de Cortés eran en verdad heroicas.

Díaz del Castillo cuenta en su Historio verdadera la narración sobre una culebrina fundida de plata y oro bajo, labrada con muchas figuras, llamada "Ave Fénix». Llevaba una leyenda - según el capellán de Cortés, Gómara, hecha por él mismo- que decía: «Aquesta ave nació sin par; yo en serviros $\sin$ segundo; y vos sin igual en el mundo.» Un lema que - según las fuentes - produjo, por su arrogancia, mucha envidia y cólera contra Cortés entre los duques y marqueses de la corte imperial en España, sobre todo entre quienes querían sustituir al poderoso Cortés en el Mundo Nuevo. Esta culebrina fue enviada a España, como obscquio al emperador, por un criado de Cortés llamado Díaz de Soto después que Cortés venciese a todo Méjico. El nombre «Fénix» estaba relacionado con la composición de los metales usados por su fundición. En su cuarta carta al emperador, Cortés da una descripción de esta culebrina de plata y oro, pero no menciona el lema. Cuenta al emperador los enormes gastos que supuso su fabricación y cuántos pesos de oro le ha costado el hacerla: 27.000 pesos de oro. Al parecer, existen noticias sobre su historia posterior. Se dice que fue fundida para servir a otros objetos.

$$
* * *
$$

Cuando Cortés, en el año 1528, siete años después de su conquista definitiva de Tenochtitlán (Méjico), regresó a España para entrevistarse con Carlos V, lo primero que hizo fue dirigirse al monasterio de Guadalupe como peregrino para dar gracias a la Virgen extremeña. Traía ricos regalos para la Virgen como exvotos. Entre ellos, como el más precioso, la famosa Iguana de oro, esmeraldas de gran valor, más rubíes y perlas. Esta iguana todavía existe y está descrita en el Libro de Capellanías, Lámparas y Bienbechores de Guadalupe. Joya tan preciosa e histórica fue, en 


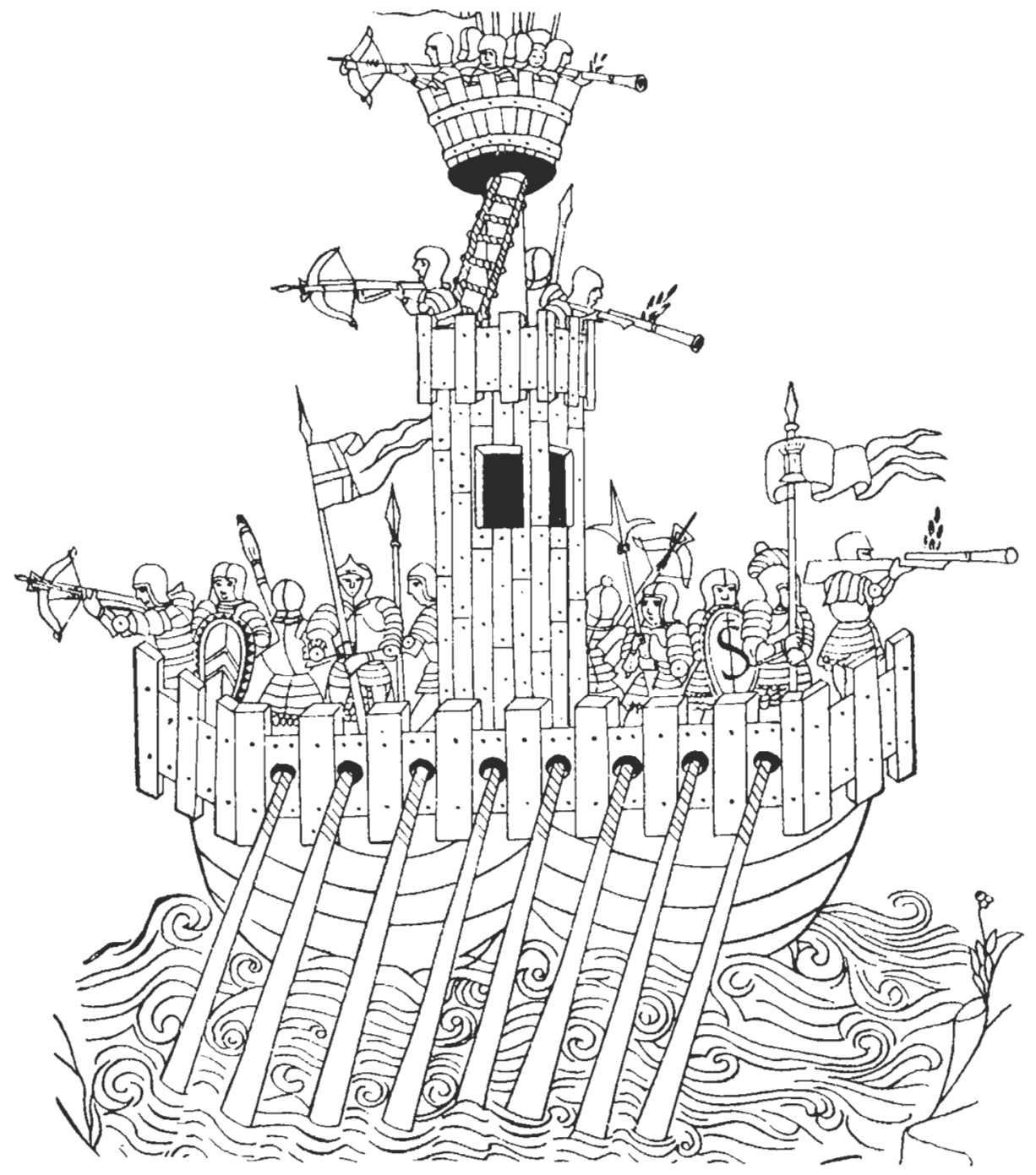

Fic. 9.-.-Navio de guerra con ballesteros y escopeteros. Los guerreros, armamento de hierro completo. Según Robertus Valturius, fin del siglo xv. Es probable gue los soldados de Cortés usaran rodavía escoperas casi del mismo tipo, según sus propias cartas al empelador. 
el siglo pasado, a las manos del entonces conde de Valencia de Don Juan, Juan Crooke, y como herencia, después, a las manos de doña Ádela Crooke de Osma. Se encuentra en la actualidad en el Instituto de Valencia de Don Juan, en Madrid.

\section{LAS ARMAS DE LOS AZTECAS}

Cuando Cortés, en febrero de 1519, desembarcó en el río de Tabasco con su pequeño ejército, encontró una población que no se dejó atemorizar por los guerreros blancos. Tuvo que luchar contra ellos. Después de vencerlos en un duro encuentro y con mucha artillería, los caciques de este lugar fueron a Cortés of reciéndole, como pacto de paz, regalos de gran valor. Entre ellos, unas veinte muchachas, que fueron distribuidas entre los oficiales y después bautizadas. Una de ellas se quedó con Cortés. Era una joven que en el bautismo recibió el nombre de Marina, o Malinche. Casi siempre aparece en los textos como Doña Marina. Era azteca de nacimiento, de alto rango, pero fue vendida por su madre como esclava a Tabasco. Llegó a una posición muy especial como intérprete y secretaria o consejera de Cortés durante toda la conquista y su estancia en Nueva España. Hablaba varios de los idiomas de estos países, más el suyo propio, el náuatl o azteca, así como el de los mayas de Yucatán. Pronto aprendió a hablar en español. Fue para Cortés una ayuda enorme durante toda la conquista. Tuvo un hijo con Cortés, llamado Martín, y más adelante Cortés la casaba con uno de su séquito. Marina aparece varias veces en ilustraciones; por ejemplo, en el Lienzo de Tlaxcala.

Desde Tabasco embarcaron Cortés y su cjército al lugar que después fue llamado Villa Rica de Vera-Craz. La ciudad de Vera-Cruz fue fundada por él, cuando se había liberado de la supremacía de Diego Velázquez, el mandatario de Cuba y las islas, y se había hecho independiente.

La zona de Vera-Cruz estaba ya bajo dominio de los aztecas. Desde este lugar comenzó su marcha y sus contactos con el jefe de los aztecas, Moctezuma II (1502-1521), en la capital, Tenochtitlán, construida en islas en el lago de Tezcoco, casi como una Venecia americana. Esta ciudad fue más tarde arrasada por Cortés durante el asedio a la que la sometió en el año 1521, pero luego la reconstruyó él mismo en estilo español y con el nombre de Méjico. Desde Vera-Cruz comenzaron Cortés y su ejército la marcha por el país desconocido, encontrando una población muy característica. Era dirigido por una clase de sacerdotes y guerreros poderosos y despóticos, con numerosas personas de varias categorías y rangos, todos mandados por un caudillo-cacique casi todopoderoso. Era un Estado lleno de poder, organizado hasta los mínimos detalles y escalonado en 
muchos grados y ramos. Aparte de su dictadura, su crueldad y sus sacrificios sangrientos de seres humanos, era un Estado que hacía siglos salió de una situación de barbarie, un Estado con una civilización a un nivel alto. Su dios supremo era el dios de guerra, Huitzilopochtli o Mellxilli (Fig. 14), a quien fueron sacrificados todos los prisioneros de guerra. Su sangre le fue presentada y bebida por este dios, y le regalaron el corazón, sacado del cuerpo en vivo. Se trataba de miles de víctimas anuales, sacrificadas en altares especiales en ceremonias sacrales: el sacerdote, abriendo el pecho del prisionero, todavía con vida, con un cuchillo especial de obsidiana con mango decorativo y esculpido, sacaba el corazón para ofrecérselo a su dios. La guerra era para este pueblo casi como una guerra santa. En las contiendas los sacerdotes iban a la cabeza del ejército para estimular y fanatizar a los guerreros. Existían honores y condecoraciones, en forma de insignias y medallas, para llevarlas al cuello por una cadena, más cintas de color rojo para los cabellos y orlas de algodón. El número de estas orlas daba razón de cuántas hazañas de mérito había alcanzado su dueño. La categoría más baja de la nobleza - los más jóvenes- correspondía en cierto modo a los jóvenes escuderos, españoles y occidentales, que acababan de recibir su «espaldarazo». Era necesaria la entrada en esta clase de nobleza baja para así poder escalar las clases y categorías más altas. De la categoría de su clase dependían sus tipos de traje y sus armas permitidas. El guerrero corriente, el soldado raso o el «obrero» de la sueria, estuvo fuera de todo esto. A él sólo le era permitido un cinturón especial o un tipo de falda corta, el maxilall, con los colores de su jefe. Su cuerpo era pintado asimismo con los colores y símbolos de su jefe.

Como ya hemos dicho, William H. Prescoll, en 1843, en su obra History of the Conquest of Mexico (vol. II, págs. 8 y sigs., ed. inglesa), ha dado una descripción muy interesante del ejército de Tlaxcala, quizá un tanto romántica, pero con muchos detalles de importancia; por ejemplo, cuando salieron de la capital para encontrarse con el capitán general Cortés y sus tropas. Esta descripción se basa en los relatos españoles de la época de la conquistá y de lo sucedido después, especialmente en la obra de fray Bernurdino de Sabagún, aunque también aportan datos fuentes como Díaz del Castillo y otras. Dice allí: «Nunca ha existido cosa tan pintoresca como esta muchedumbre de guerreros para batalla con sus cuerpos desnudos y pintados, los caudillos y jefes con sus preciosos cascos brillando de oro y plata, con su resplandor de piedras preciosas, penachos de plumas largas y multicolores, luciendo un maravilloso mosaico de plumas, sus enormes lanzas y sus jabalinas arrojadizas, con sus puntas transparentes de obsidiana o las puntas de cobre de un rojo ardiente, brillando en la aurora, parecido al brillo del fósforo en la superficie del mar mareado, la retaguardia y su enorme masa de colores variados en la sombra de 
los estandartes preciosos, con las armas heráldicas de los grandes caudillos de Tlaxcala, rico en esmeraldas y decoraciones de plata.» La gran masa de guerreros iba - como ya hemos dicho- desnuda, pero pintada con varias insignias y figuras en color, con sus cinturones y la heráldica con los colores de sus caciques. Todos los guerreros de categoría alta vestían escaupiles y túnicas gruesas, fabricadas hasta las rodillas. Encima de éstos llevaban corazas de escamas finas de oro y plata, entre ellos también escamas en forma de caracoles, etc. Sus piernas estaban protegidas por una clase de botas o medias botas de cuero fino y ricamente ornamentadas con decoraciones en oro y plata. La parte más vistosa de su traje guerrero ela su capa riquísima, hecha de una tela fina y cubierta con plumas, cosidas con gran arte, con figuras y ornamentos en los colores pertenecientes a sus dueños y el rango de éstos. Sus cascos - de madera o de cuerotenían la forma de algún animal de la selva: ocelote, jaguar, águila u ottos, en sus colores propios, y la cara ornamentada con los dientes naturales de los animales, con la boca abierta, por donde podía verse la cara del guerrero. Cada animal significaba un rango especial. Arriba, en el apex, aleteaba un enorme penacho con plumas largas. La forma y los colores de este penacho también indicaban el rango, la categoría y el estado social y militar - hasta los príncipes- de su dueño (Figs. 14-16). Los escudos eran los redondos chimallis, la mayor parte de ellos con una falda de tela o de plumas en mosaicos de tipo heráldico y simbólico. Así vestían - según las descripciones que nos da el padre Bernurdino de Subagún (y copiados por William Prescoıl y otros científicos) — los ejércitos de Tlaxcala en el segundo desfile en honor de Cortés y saludando al capitán general español con movimiento de los estandartes. Los cuatro grandes caudillos marchaban a la cabeza (Fig. 15). Sus escuderos traían sus armas y sus colores. Después seguían los guerreros de combate, precedidos por la música de timbales, tambores, trompas y cornetas. A continuación, los comandantes ricamente vestidos. Debajo de su brazo izquierdo portaban sus yrandes espadas, sus maquahitls, con los filos en forma de láminas de obsidiana engastadas en la madera y con sus puntas hacia arriba. A su lado caminaban sus escuderos, con los chimallis de sus amos. Los comandantes tenían sus estandartes y banderas hechos de redes ricamente bordados con plumas en figuras heráldicas con mucho oro. Las diversas ciudades tenían sus propias banderas: Méjico, con un águila con un leopardo en la boca; Tlaxcala, un águila dorada, según algunas de las fuentes. Las descripciones que nos ofrece Bernardino de Sahagún sobre estos ejércitos, con sus armas, decoraciones y símbolos, son bastante detalladas. Describe toda clase de detalles respecto a material, forma de los «casquetes» de guerra, con varios tipos de plumas, largas o en forma de coronas, manojos de plumas coloradas, usados como penachos, que llegaban hasta la espal- 
da; el oro usado y muchos detalles dorados (Firs. 18). También menciona sus «cosetes» de plumas, que colgaban hasta medio muslo de los guerreros, sembrados con caracoles de oro, más unas «faldetas» de plumas. Llevaban collares de turquesas y otras piedras preciosas, finas y redondas. Bernardino de Sahagún también da los nombres de otros detalles, más explicación de sus colores. Además ofrece la descripción de los escudos, su material, colores y heráldica, con nombres y maneras de llevarlos.

Aparte de estas descripciones tan detalladas tenemos las armas de los aztecas y los mayas, conocidas por sus representaciones en el arte, especialmente de los códices hechos despućs de la conquista, con sus sencillos dibujos en color. Existen también representaciones escultóricas y en relieve de los aztecas y mayas de la época, y respecto a los mayas, pinturas murales y cerámica pintada de las épocas anteriores. A pesar de que estas representaciones son tan estilizadas y ornamentadas, y una explicación de ellas resulta muy difícil en ocasiones, tienen un gran interés.

\section{LAS ARMAS OFENSIVAS}

Los conquistadores llegaron a un mundo lleno de sorpresas, un continente dominado por arcos y flechas, más estólicas y tiraderas. Probablemente, la tiradera lanzada por el estólica fue la sorpresa más desagradable para ellos. Entre las otras armas ofensivas estaban las lanzas, jabalinas arrojadizas, dardos, varios tipos de mazas y macanas, porras y rompecabezas estrelladas, de un tipo especial para los incas. De gran importancia eran sus espadas, los maquahitls, más dagas, cuchillos y hachas de piedra. Hondas y boleadoras no eran tan corrientes en Méjico, entre los mayas y los incas, como en las regiones de las grandes llanuras, por ejemplo, la Pampa en Argentina.

El arco se fabricaba corrientemente de una madera especial, fuerte, flexible y bien preparada, con gran trabajo e inteligencia. Los arcos compuestos no se conocían entre los indios de esta parte de los continentes americanos (Figs, 11-13). El tamaño variaba bastante, según regiones, tribus y nivel de cultura, al igual que el material, que dependía de la vegetación y del clima. La cuerda podía ser de cuero especialmente preparado, pero lo más corriente es que fuesen de fibras de ciertas plantas, idóneas para este fin. Era un arte la fabricación de estas cuerdas para arcos; lógicamente, ser fuertes era la condición para que soportasen bien la tensión del arco de una madera dura. Para los españoles era muy difícil aprender a tensar estos arcos. Los indígenas lo hicieron con gran facilidad y rapidez, pero era necesario que protegiesen sus brazos izquierdos con una manga larga hasta el codo de piel fresca de venado o de cuero espe- 


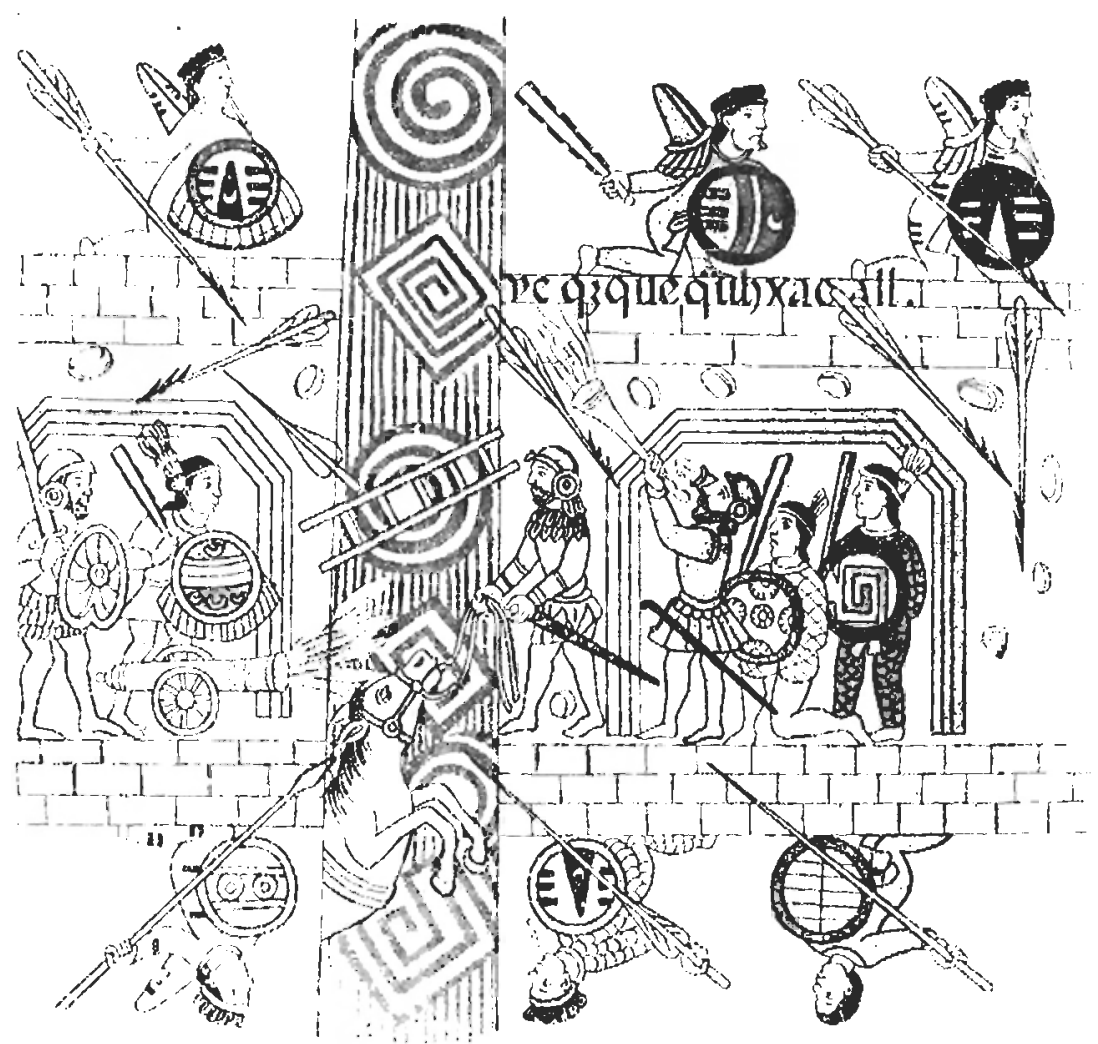

FIg, 10.-Los españoles de Cortés y sus aliados indígenas de Tlaxcala luchan en la ciudad de Méjico conrra los azrecas. Nótese el cañón y la escopeta (casi un trabuco de tipo andalu\% para bandoleros). Un caballo ha caído en una canal de la ciudad. Está para ser rescatado (Lienzo de Tlaxcala).

cialmente preparado para recibir la percusión. Los aztecas tenían talleres especiales para la tabricación de arcos y de flechas. El lugar era cl patio en el templo del dios de la guerra, Huitzilopocbuli (Fig. 14). El astil de la flecha solía ser de caña, pero también los fabricaban de madera. La punta, normalmente, era de obsidiana o de cobre, y en las costas, también de espinas de ciertas clases de peces. Tenía una forma especial, pero existían varios tipos (Figs. 10-13). La mayoría de estas flechas producían heridas mortales, pero había otras que, al ser imposible su extracción, quedaban en las heridas. Uno de los conquistadores, Bartolomé García, 


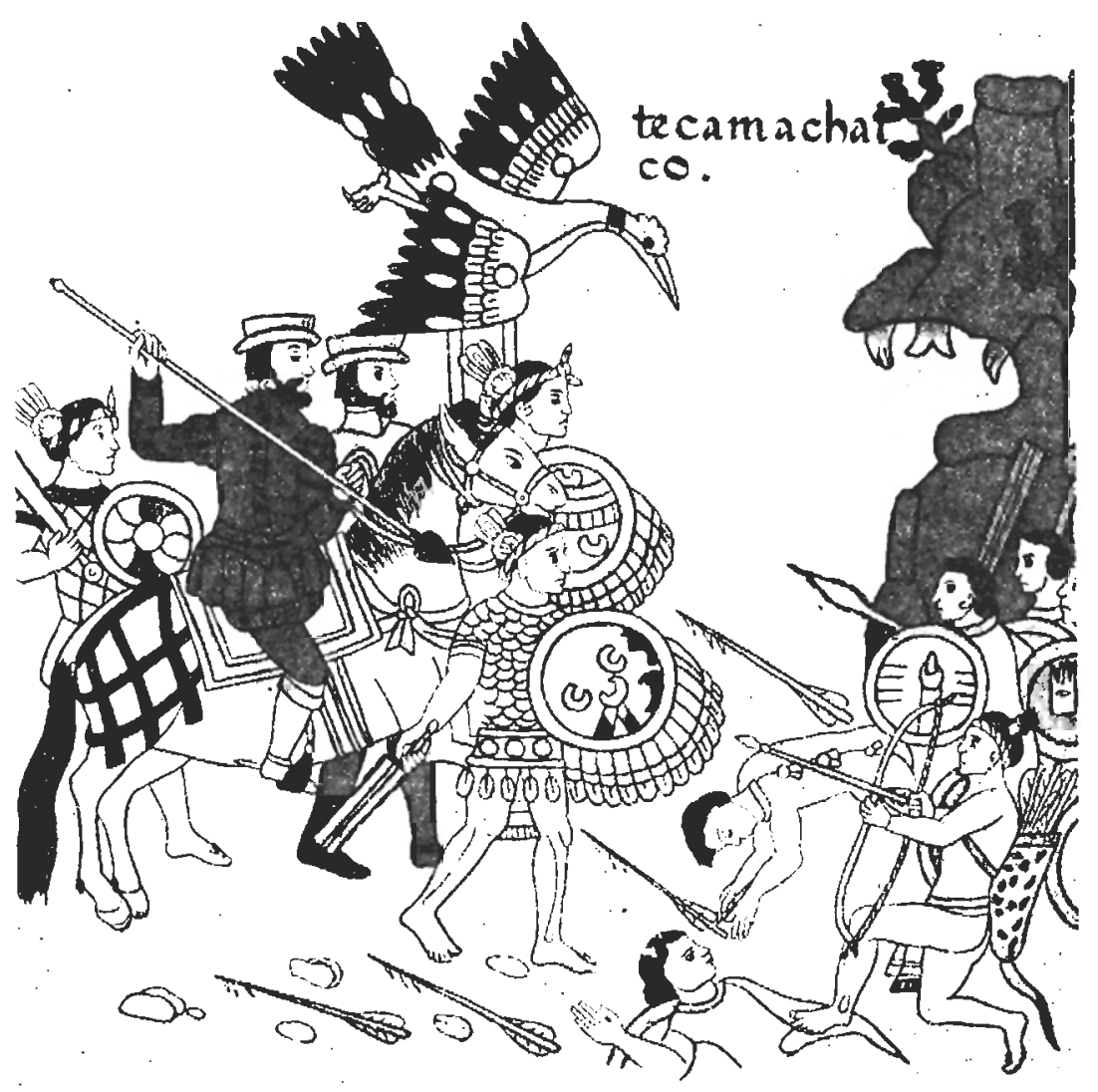

FIG. 1.1.- Jinetes españoles con sus aliados indígcnas luchan contra los azlecas de Tccanachalco. Nótese el cambio de vesticlos y la diferencia entre los indígenas de Tlaxcala y los aztecas (Lienzo de Tlaxcala).

se queja en una carta de 1556 al Real Consejo de Indias, y cuenta cómo una punta de flecha se quedó en su brazo durante cinco años. Una especialidad importante era el emplumado de los astiles. Las plumas eran fijadas casi al final del astil con una cola fuerte, que daban a las flechas más estabilidad. Los plumeros, frecuentemente, se hacían en forma de espiral, dando a la flecha un movimiento de rotación y más fuerza en la penetración. (Investigadores norteamericanos han llamado a este fenómeno rifling.) Algunas de las puntas tenían dientes y hasta dos o más puntas. 


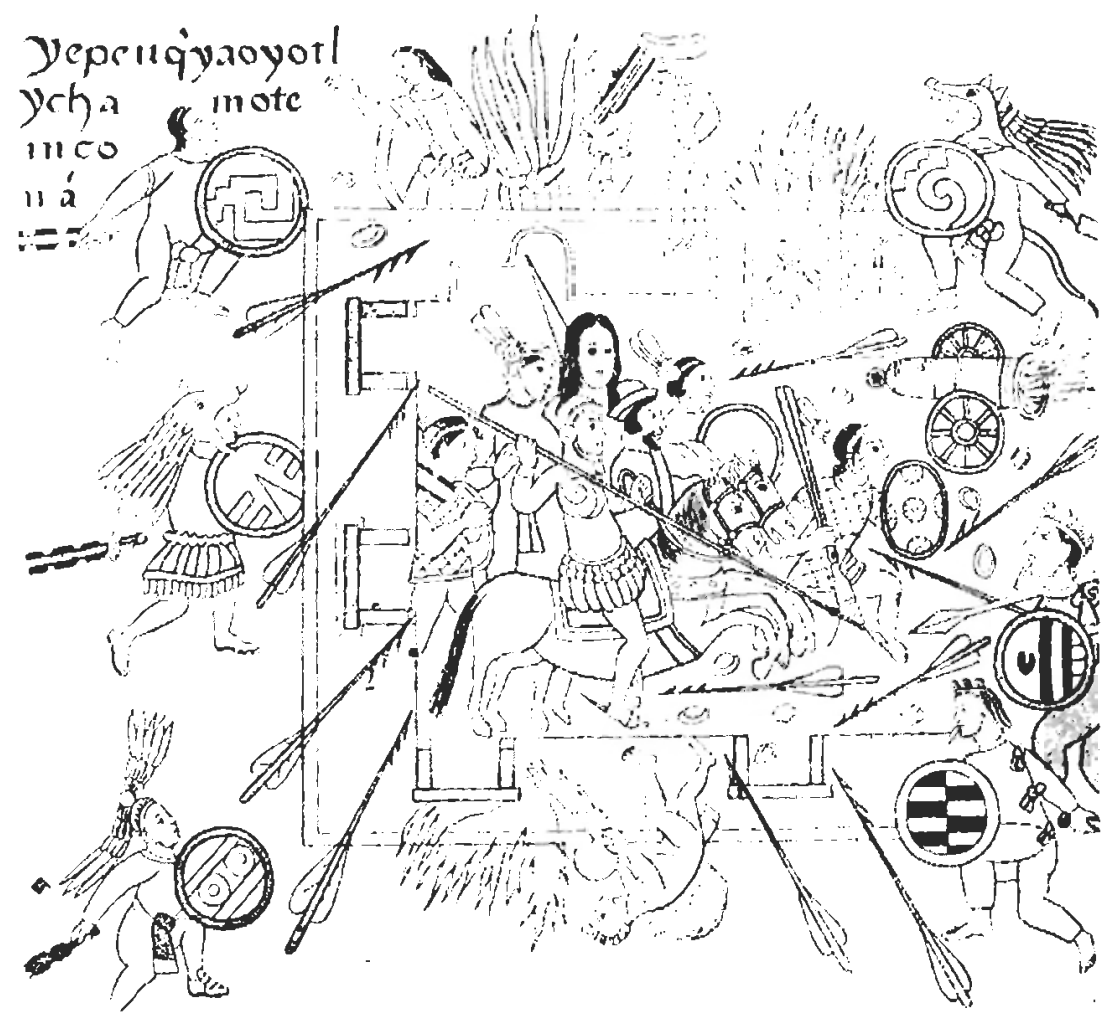

Fig. 12.-Los españoles, con Cortés en el centro y con sus alialos indigenas, luchan en Méjico contra los aztecas. Nótense el cañón a la derecha, los dardos y los maquahitls (Lienzo de Tlaxcala).

Su extracción era imposible. Los conquistadores temían a estas flechas. Se transportaban las flechas en una aljaba suspendida en el dorso de una manera especial, de manera que resultase fácil cogerlas en un movimiento rápido y con un mínimo de tiempo. Según las fuentes, se pudieron disparar hasta veinte flechas en un minuto. Cortés, en una carta, habla de la inmensa manta de flechas que cubría el suelo en su patio en Méjico después de un ataque. Numerosas flechas se engancharon en los escaupiles de los hombres y caballos. Pero la mayoría de ellas no llegaron a herir ni a sus hombres ni a sus caballos. 


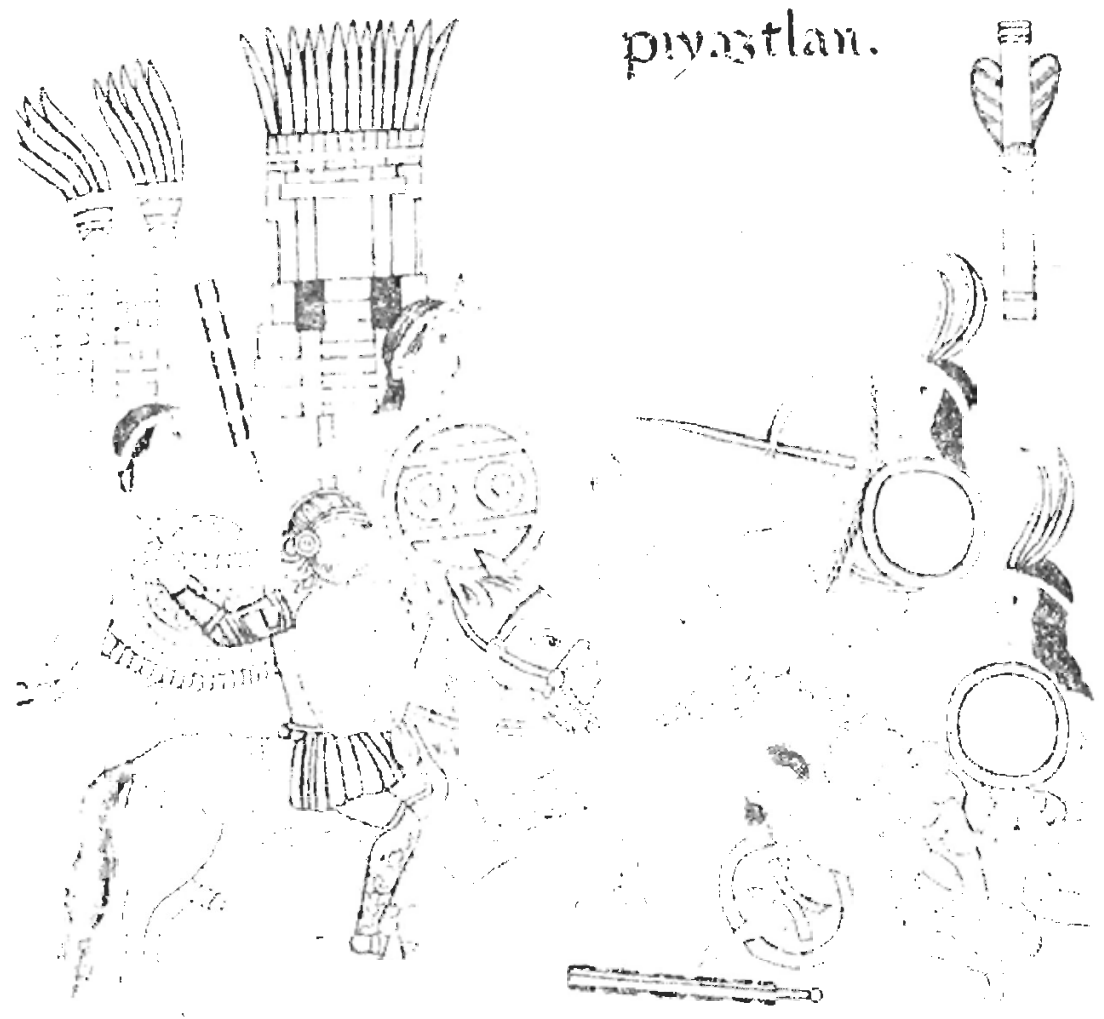

ГIti. 13,- Lucha entre españoles, indígenas aliados y aztecas en el mismo Méjico. Nótense los maquahitls de los indios (Lienzo de Tlaxcala).

Estólica con liruderas. Después de la flecha, la estólica (allall) era una de las armas más usadas por los aztecas y también por los incas. Estólicas con tiraderas - estas últimas, una clase de dardos pequeños o flechas grandes-, de origen antiquísimo, se pueden ver en muchas ilustraciones, especialmente en esculturas y relieves de los mayas y en su cerámica pintada, así como en el arte de los incas. Dar una descripción de este aparato resulta difícil. Consiste en un simple mecanismo en forma de palanca, de madera, con un pequeño gancho especial en uno de sus extre- 
mos. Sobre éste se apoya la parte posterior de la tiradera, de modo que ésta y el propulsor quedan paralelos. El aparato prolonga y acentúa el vigor del brazo, de modo que el dardo tiene más penetración llegando desde gran distancia.

Hay tipos sencillos y otros más complicados. En el arte mejicano pueden ser ricamente ornamentadas, cubiertas de láminas de plata o de oro, o pueden tener ornamentación grabada en la madera. Algunas veces sólo queda en simbólica, una piña de plumas u otras figuras. Según las fuentes de los conquistadores, las estólicas de los incas eran más sencillas. Los romanos en la Península Ibérica, y hasta los iberos prehistóricos, habían usados propulsores para sus dardos, amentum (amientos), pero en forma de una correa de cuero. (Amentum también en manuscritos mozárabes del siglo x.) Inca Garcilaso de la Vega llamaba los propulsores «amientos de palo» y «amientos de cuerda». Según las fuentes de la época, los dardos de una estólica llegaban con una potencia tal que eran capaces de atravesar una puerta. Otras tradiciones antiquísimas nos dicen que son los aztecas los inventores de la estólica en la ciudad de Cuyııacán. Fray Bernardino de Sahagún nos cuenta que las flechas y los dardos se labraban, en días muy especiales, en el patio del templo del dios Huitzilopochtli, bajo determinadas ccremonias, entre éstas el sacrificio de esclavos, cuya sangre fue extraída por las orejas con cuchillos de obsidiana para rogar a su dios que les concediera la victoria en la guerra (véase Bernardino de Sahagún, Historia general, I [Méjico, 1938], págs. 187188 y 339).

Las lanzas largas no desempeñaron en Méjico el mismo papel que en otras partes (por ejemplo, en Chile). Su tamaño no era tan largo como las lanzas en ristre de los españoles. Los conquistadores tuvieron que cambiar esta lanza por la de los hispano-moriscos de Andalucía y luego por la de los aztecas (Figs. 10-12).

Mazas, porras y espadas. La maza o la macana, así como la porra, fueron generalmente fabricadas de una clase de madera muy especial. Existen en estos países varios tipos de madera aptos para este fin. Algunos de éstos eran tan espesos en estructura, tan duros y pesados, que no podían flotar en el agua. Se hundieron como si hubiesen sido hechos de algún tipo de metal, según explica Alberto Salas en su libro, con referencia a sus fuentes. La forma de estas mazas y porras es conocida por representaciones en el arte. Algunas tenían forma de grandes y fuertes bastones, las macanas, de vez en vez con sección cuadrada y con filos de obsidiana en forma de una o dos hachas. Eran armas peligrosísimas. Otras tienen la forma de un bastón grande, grueso en su extremo, que estaba lleno de filos de obsidiana. Corresponden casi a los famosos mazos de la mitología griega, los mazos de Heracles, Mazas y porras, en algunas regiones, se pa- 


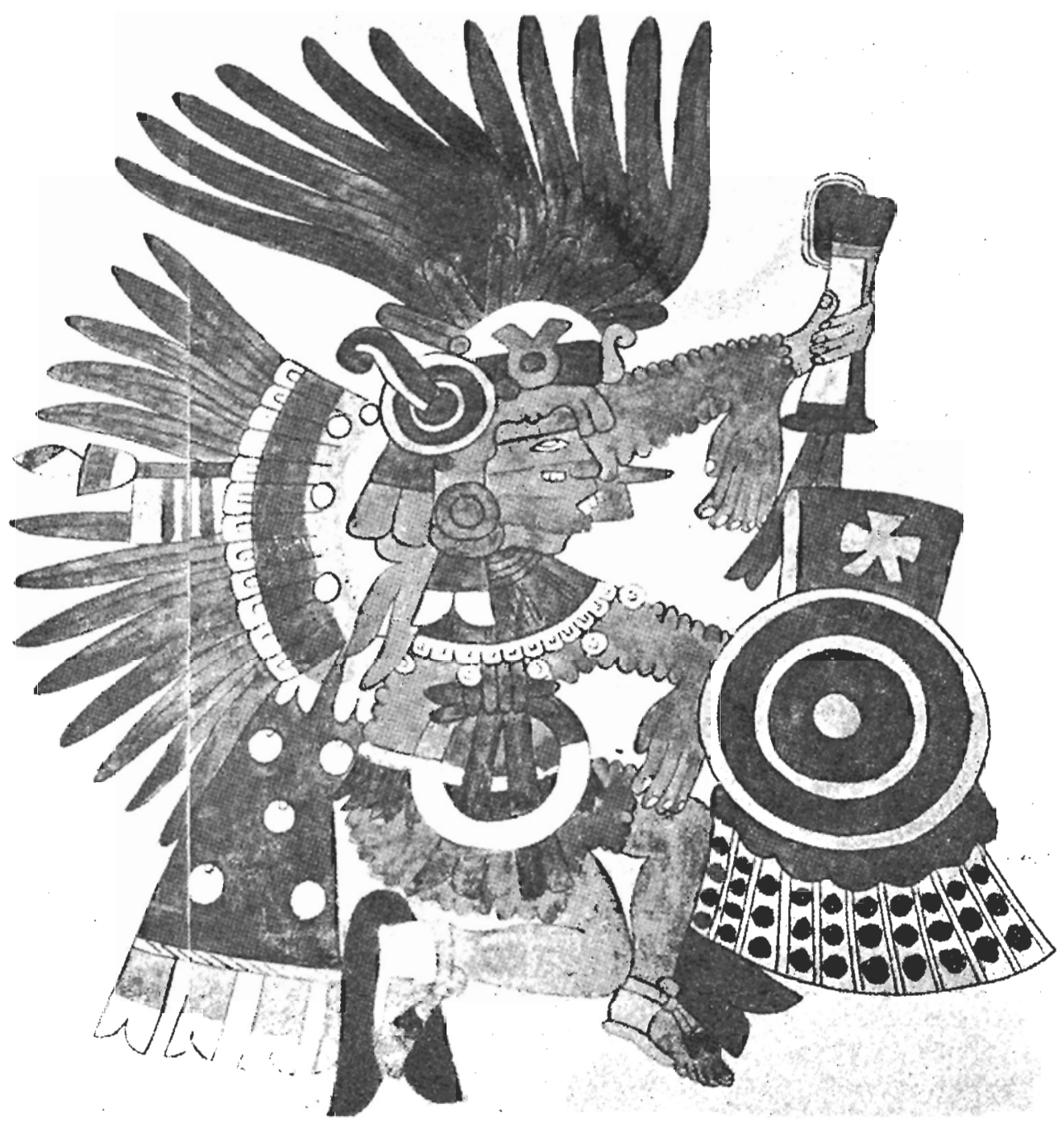

Fig. 14.-El dios de la guerra de los aztecas, Huitzilopochtli, sediento de sangre (De un códice azteca, Méjico).

recen a espadas grandes y pesadas con sus láminas de obsidiana engarzadas en ambos lados. Todas estas armas se manejaban con dos manos. Eran peligrosísimas, y según cuentan las descripciones de la época, capa- 
ces de decapitar a un caballo de un solo golpe o aplastar en un momento a un adversario. De estas armas cxisten muchas y buenas representaciones en el arte. El gran rompecabezas estrellado era una especialidad entre los incas. En Méjico, la maza fue convertida en una espada con dos filos, el maquahitl, un arma larga y sólida, algunas veces gruesa y como un bastón; otras veces más delgada, como una espada de metal. Los dos lados del maquahitl tenían cada uno un filo de láminas de obsidiana engarzadas en la madera (Figs. 11-13). Estas láminas, agudas y cortantes, se colocaban con breves intervalos y alternando las de un lado y las del otro. El «cemento» usado para su sujeción era una clase de arena especial, recia, y como vena de diamantes, mezclado con sangre de murciélagos y varias clases de aves. Esta masa, endurecida, y los filos no se rompieron con un golpe duro. Estas armas se usaban en una clase de esgrima, normalmente con ambas manos y cuerpo a cuerpo. Según Cristóbal Colón, que las había visto en función, eran armas horribles. Existen buenas ilustraciones de este tipo de armas en el arte mejicano y también en el maya. En Perú existían espadas del mismo tipo, pero con filos de bronce. No eran tan corrientes como en Méjico.

Hay bachas de varios tipos, de piedra o de obsidiana. Preciosos y cortantes tipos de cucbillos de obsidiana existen para uso sacral en los templos, cuando se sacrifican víctimas para los dioses. Se asemejan algo a los cuchillos sacrales de los templos egipcios de las primeras dinastías faraónicas.

Las bondas y boleadoras se conocían, pero no parecen haber tenido excesiva importancia en Méjico. Resultaban ser unas armas peligrosísimas para los caballos, pues con una gruesa piedra lanzada por una honda era fácil matarlos. Una piedra así lanzada destrozó la cabeza de un hombre que no llevaba colocado el casco de metal; de este modo murió Juan Pizarro en Cuzco, Perú, cuando no llevaba protegida su cabeza. Con una boleadora, con sus dos o tres bolas en correas de cuero o fibra, se consiguió con facilidad tumbar a un caballo.

Las armas envencnadas y los gases tóxicos no fueron usados en Méjico, al menos aparentemente, aunque se conoce el uso en muchas partes de los dos continentes americanos. Los gases se utilizaron, por ejemplo, en Canadá, entre los indios de aquella parte del mundo. Gases tóxicos se produjeron en algunos sitios con humo de pimientos.

«Armas secretas» existían en forma de trampas en el suelo. Pequeños agujeros u hoyos en los bosques y campos representaron un gran peligro para el hombre montado y su caballo. Al no ser apreciados estos hoyos, el caballo y su jinete inevitablemente caían, y una vez en el suelo ambos eran víctimas fáciles a manos de los indígenas. 
Estas armas variaron en casi todas las regiones según el nivel de cultura, clima y necesidad. En las dos grandes civilizaciones, as ́x como entre los mayas, ya durante los siglos anteriores, las armas defensivas llegaron a tener un nivel alto y muy característico. Este tipo de armas fue para los conquistadores otra gran sorpresa.

El escaupil era la defensa más importante entre todos los tipos. Los conquistadores no tenían más remedio, en sus luchas y batallas, que adoptar esta defensa para los hombres, los caballos y los perros. El escaupil está bien representado en casi todas las artes, desde los monumentos antiguos de los mayas y toltecas hasta el fin de la conquista de Méjico y Perú. En realidad sólo es una clase de sayo - en el Norte, especialmente entre los canadienses y los esquimales, un «anorak», como se ve todavía hoy día- estofado con algodón por dentro y con una tela, cuero crudo o piel fuerte por fuera. Puede también ser fabricado con varias mantas sobrepuestas sobre el canvas o cl cuero. Había varios tipos: pequeños, que sólo cubrían el pecho, realmente una clase de peto y dorso, una clase de coracina, cuirasses o una brigandina (sin metal por dentro). Otros eran más largos, que a veces llcuraban a las rodillas. Existían también tipos que cubrían brazos y piernas. Así puede verse en las representaciones de los mayas. Algunos eran airosos y ligeros, otros gruesos y pesados (Fig. 18). Según algunas descripciones, entre otras las de Pedro de Alvarado en una de sus relaciones, los había tan incómodos y pesados «que el que caía al suelo no se podía levantar por sí mismo y con sus armas por el peso y rigidez de estos coseletes de tres dedos de algodón y largos hasta los pies». Otras descripciones dicen: «Eran aquellas armas unos sayos con mangas hasta en pies, de algodón torcido, duro y de tres dedos de gordos. Parecían bien con los sacos, como eran blancos y de colores, con muy buenos penachos que llevaban en las cabezas» (Fig. 18). «Eran tan gruesos como colchones de una cama», según otros autores.

Al parecer fue Colón, en su cuarto viaje a Centroamérica, la primera persona que vio esta protección. El escaupil es mejor conocido en Méjico y entre los mayas que en otras civilizaciones. Se reproduce no sólo en relieves y dibujos de la cerámica azteca y maya, sino especialmente en los diversos códices hechos después de la conquista. En estos códices podemos ver que cubren la mayor parte del cuerpo y tienen una fuerte protección para brazos y piernas, estando ricamentc adornados con largas plumas coloreadas. Bernardino de Sahagún nos da varias descripciones de escaupiles, que, para los aztecas de altá categoría, llevan además una especie de peto o coraza hecho de escamas de oro y plata por encima. Entre éstas se veían figuras y adornos de los metales preciosos en forma de 
caracoles y animales parecidos. Todavía más fuertes, con más protección para brazos y piernas y con aspecto más fantástico, casi indefinibles, son las representadas en los relieves de los mayas. Muchos de sus ornamentos tienen significados simbólicos, divisas y heráldica. El Códice Mendoza nos of rece explicaciones de estos símbolos y las insignias de la clase. Según las fuentes, entre otras la de Bernal Diaz del Casilllo, que da una descripción de la gran armería de Moctezuma en su palacio (que, según Charles Lummis, en su libro sobre los exploradores españoles, solamente han sido unos edificios hechos de adobe), había muchas armaduras de algodón acolchado con plumas de muchos colores. Existen representaciones de guerreros toltecas luchando con aztecas vestidos con escaupiles muy gruesos, cubiertos brazos y piernas y con enormes cascos en la cabeza; estos cascos portaban grandes penachos de plumas largas. Sus armas ofensivas en esta lucha son estólicas y tiraderas además de dardos.

Los cascos son aquí, como en la mayor parte de las ilustraciones, de madera o de cuero, con forma de cabeza de jaguares, ocelotes y leopardos y también águilas (Fig. 18). Las bocas están abiertas, mostrando los fuertes dientes; detrás de éstos se podía ver las caras de los guerreros. Sobre estos tipos de cascos, así como otros detalles de las armas defensivas, Bernardino de Sabaguin nos ofrece unas descripciones detalladas y muchísima información. Todos tienen una ornamentación riquísima, con dibujos y metales preciosos, más mosaicos de plumas coloreadas, hechas en forma de heráldica y símbolos u otras figuras protectoras. Otros autores dan descripciones de los cascos de los incas, los cuales son algo diferentes de los de Méjico. Los cascos de Perú se hacían de metal, hasta de oro, cobre u otra clase (como se puede ver en algunos museos, entre otros en el Museo de América de Madrid). Pero también existen cascos fabricados con láminas de algodón, finamente torcido, que daba como resultado una masa fuerte y resistente contra los golpes de mazas y maquahitls. También los había hechos con cañas finas, tejidas con algodón, tan resistentes a los golpes de los rompecabezas y piedras, que no eran posible herir al guerrero.

Los escudos. Según Pedro de Aguado, en su obra Hisloria de Sanla María y el Nuevo Reino de Granada, I, págs. 634-635, los indios usan allí «unos escudos o paveses de cuero de ante seco y tieso, que es gran anparo y defensa y muy ligero. Estos escudos train los yndios colgados al pescjueço y quando peleaban y xugavan de sus lanças los echavan delante para anparo de las barigas, y cuando se retiraban o huian, cosa muy comun y nada vergonzosa para ellos, se los echavan muy ligeramente a las espaldas, colgadas del pesqueço como los tenian y asi se huian, yendo adacgados y arodelados por detras, que les era harto remedio para no recibir mucho daño de los que yvan en su alcance». 

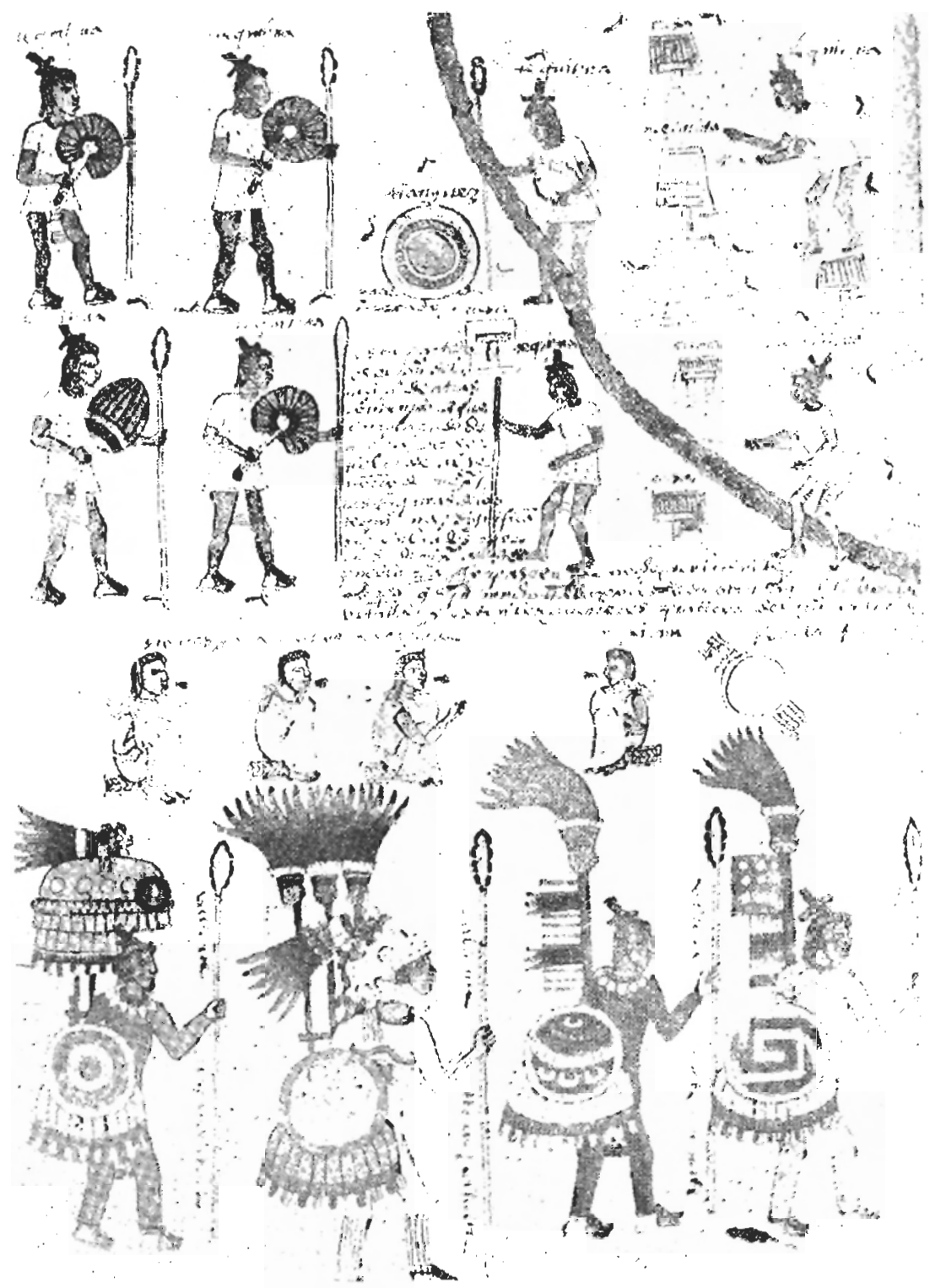

Fig. 15.-Los cuatro grandes jefes militares en Méjico con sus trajes característicos, con cascus $y$ emblcmas lípicos. lanzas con láminas de obsidiana y chimallis con faldas. Arriba, guerrerus aztecas penctran en territorio rebelde en Méjico (Códice Mendoza). 


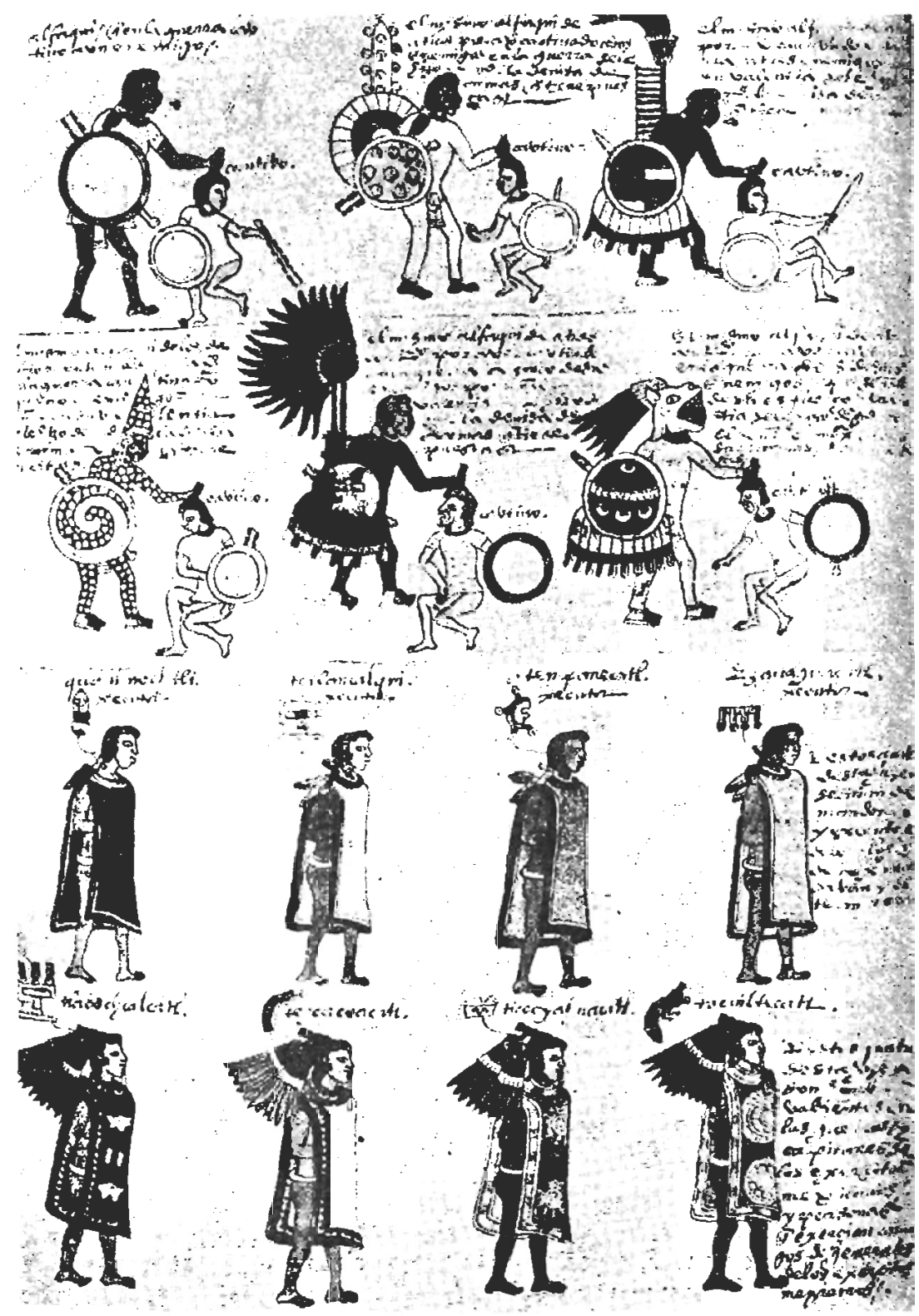

F1G. 16.-Guerreros aztecas capturan enemigos para llevarlos al sacrificio sangriento. Abajo, personas de alto rango con los trajes correspondientes a sus categorías social y militar (Códice Mendoza). 
El escudo característico de los aztecas era el chimalli, un escudo redondo con un diámetro aproximado de $80 \mathrm{~cm}$, hecho de un cuero fuerte, bien preparado. Por dentro estaba construido de cañas sujetas con fibras. Abajo tenía una especie de falda de cuero o de tela con mosaicos de plumas, con símbolos, heráldica y animales preventivos. Según Bernardino de Sabagúr, había varias categorías de chimallis, cuya construcción era diferente, cada tipo con sus significaciones. El Códice de Mendoza nos informa muy bien sobre estas categorías (Figs. 14-18). Ofrece este códice unas representaciones de guerreros aztecas de alta categoría con sus escaupiles, cascos de animales, penachos largos de plumas, sus rodelas corrientes de tabla de madera y un marco de metal y los chimallis con sus faldas. Una representación nos muestra a los tequihuas penetrando en territorios rebeldes al señorío de Méjico en función de espías (Fig. 15). Los guerreros tienen escaupiles pequeños, chimallis sin faldas y símbolos, y sus armas son lanzas largas con filos de obsidiana.

Pero al lado de éstos había unos paveses grandes - como dice Pedro de Aguado - que cubrían casi todo el cuerpo del guerrero y fabricados con un cuero grueso y fuerte, en regiones más al Norte probablemente de bisonte o de oso; estos paveses eran buenos protectores contra las ballestas. También estos escudos tenían generalmente pinturas o mosaicos de plumas con heráldica y símbolos. Sus detalles estaban relacionados con sus propios significados: los colores, las figuras en sus muchas variaciones, animales, etc. Bernal Díaz del Castillo, describiendo el arsenal de Moctezuma, nos habla de unos escudos y nos da una descripción interesante: «Eran como paveses que son de arte que las pueden arrollar arriba cuando no pelean porque no les estorba, y al tiempo de pelear, cuando son menester, los dejan caer, e quedan cubiertos sus cuerpos de arriba abajo.» Podríamos decir que son como una persiana.

El escudo pertano corriente era pequeño, cuadrado y también con una especie de falda de cuero o tela. El guerrero tenía a sus espaldas unas rodelas pequeñas de varas de palma o algodón. Escudos del mismo tipo, mayores y para las manos, pero no redondos, sino prolongados como escudos heráldicos, se usaban para amparar la cabeza contra las lápidas y pedradas. En Perú existían también otros raros tipos, entre ellos unos grandes, hechos de tejido de palos y tela, en forma de rodelas, que podían cubrir hasta a veinte hombres de una vez. (Se parecen a los «techos de escudos» de los antiguos romanos.)

Muchos detalles respecto al armamento de estas grandes culturas en Méjico, Yucatán y Perú son difíciles y probablemente casi imposible para nosotros de entender, especialmente por su simbolismo, por lo que hace a figuras y colores y por su significado mágico, que quizá no lo podremos 

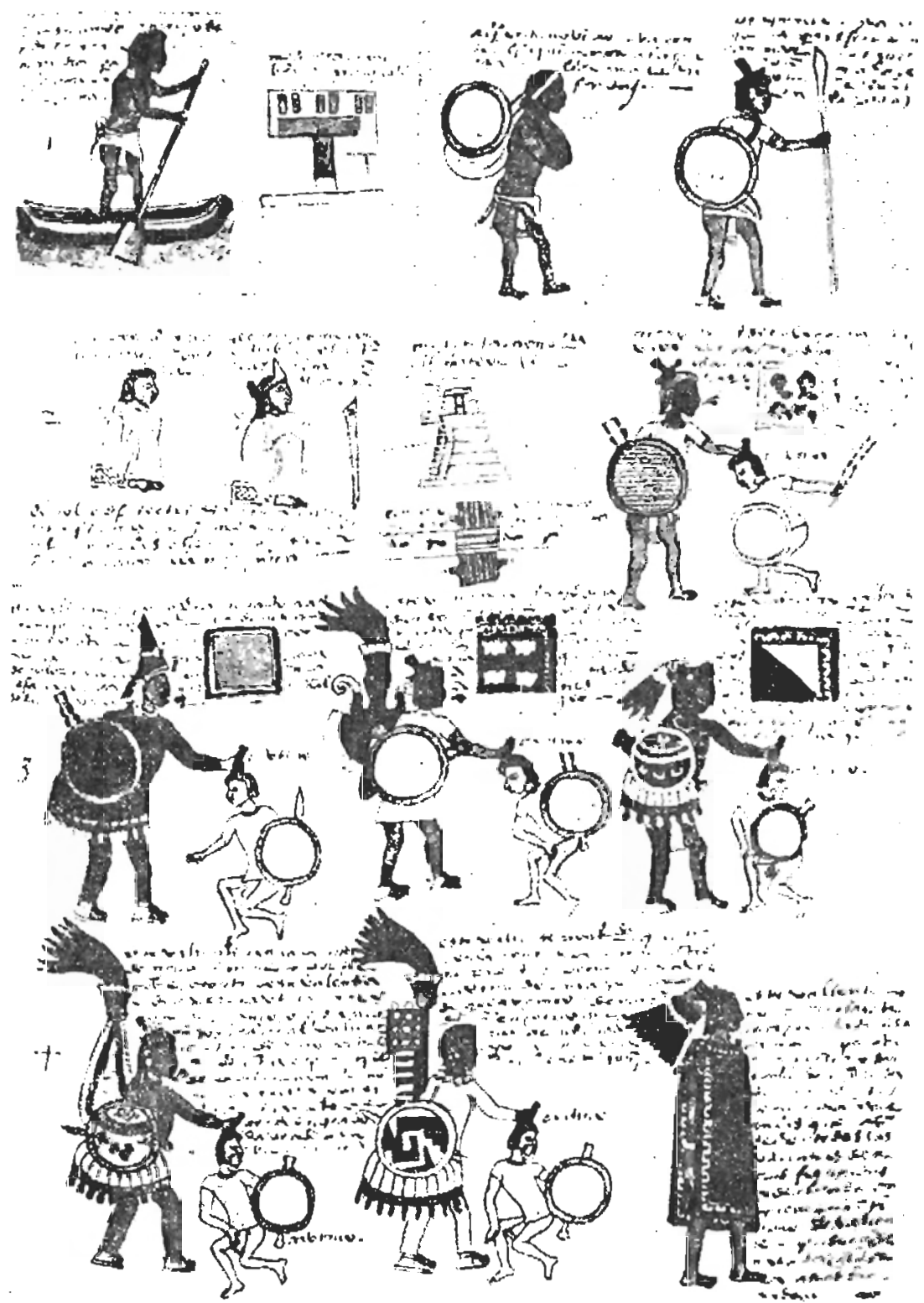

Fig. 17.-Personas de alto rango con lus honores concedidos a cllas por el número de cautivos que han llevado al altar del sacrificio (Códice Mendoza). 


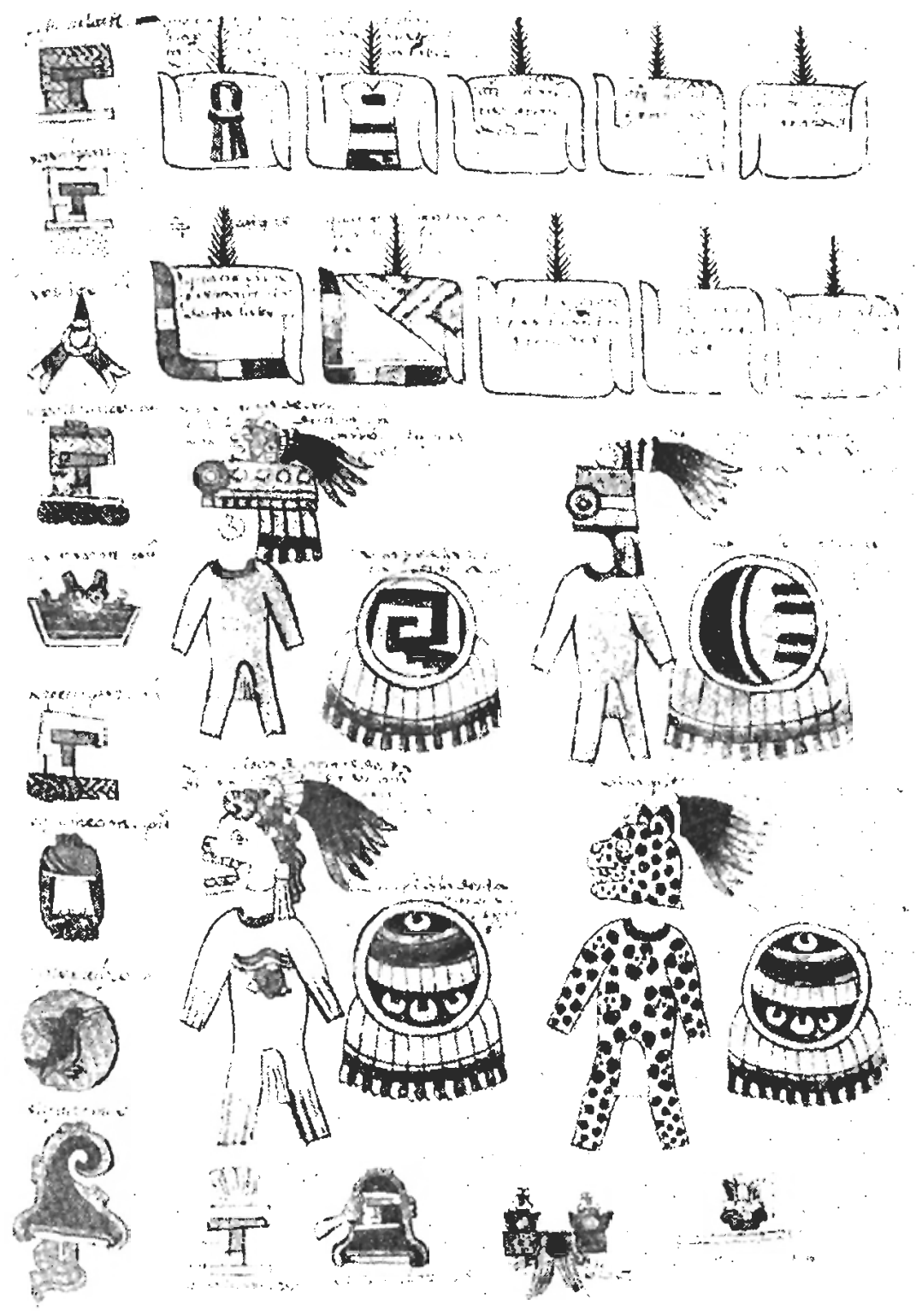

Fig. 18. - Arriba, signos de dignidad concedidos por el número de cautivos sacrificados. Abajo pueden verse cascos, escaupiles y chimallis de varias categorías y rangos (Códice Mendoza). 
aclarar, al menos hasta que no conozcamos con más detalle su religión, sus jeroglíficos y literatura, tan diferente a la nuestra.

Para entender bien el armamento de los aztecas, y probablemente más aún el de los incas en Perú, hay que estudiar su arte y su organización y arquitectura militar. En este aspecto, especialmente la arquitectura militar de Perú, por ser los incas especialistas en este ramo de la cultura. Para este fin existe en España una gran bibliografía, formada por las muy abundantes y detalladas descripciones hechas por los cronistas de estas épocas participantes en la conquista, sea como militares, sea como padres misioneros, en las muchas relaciones e informes entregados al emperador Carlos $\mathrm{V}$ y las instituciones españolas durante estos años del siglo xvi, una bibliografía que probablemente es única en el mundo de la historia. Salas, en su libro, ha investigado estos temas con mucho detalle en algunos de sus capítulos.

La organización militar en Méjico y Perú había llegado a un alto nivel, ya que eran Estados con un militarismo avanzado. Desde niños fueron educados para la guerra (como en la Grecia antigua, en Esparta), la organización militar y el entrenamiento en los diversos tipos de armas. Todos los hombres, desde los veinticinco hasta los cincuenta años, estuvieron obligados al servicio de las armas, educados en las academias militares en una disciplina rigurosa, con obediencia ciega, con castigos hasta la muerte, llegando a ser expertos y hábiles con sus armas. Para los aztecas, la guerra era la ocupación más gloriosa e importante de todas. Era para ellos algo solemne. En la estructura militar existía una graduación complicada. La posibilidad de ascenso a alguna jefatura era bastante difícil. Existía un timero de nomenclaturas cuyo significado es posible nos fuese dificultoso entender. En este aspecto, Alberto Salas ha hecho, en su libro, unas investigaciones detalladas, especialmente en sus últimos capítulos. En éstos trata el autor la Guazabara de los aztecas, La milicia indígena, La tropa bispánica y El entrevero, con muchas referencias a la literatura existente sobre escritos de los cronistas españoles. Informativa es también la investigación de varios códices, en especial el Códice de Mencloza. En sus folios puede estudiarse el armamento azteca en todos sus detalles. En uno en particular se ve a los cuatro grandes jefes vestidos con su traje militar: Tlacatucatl, Tlacochcalcall, Uitnauall y Teçocianacatl (Fig. 15). Por encima de estos cuatro grandes estaba Tlacatccutli, el superjefe. A partir de este manuscrito podemos estudiar pormenorizadamente los honores e insignias que recibieron los guerreros según la cantidad de cautivos que habían llevado al sacrificio sangriento de su dios. Es interesante comparar estas ilustraciones con las del Lienzo de Tlaxcala, donde podemos ver jinetes españoles en traje de guerra modíficado según las necesidades de Méjico; también con sus aliados indígenas, que llevan 


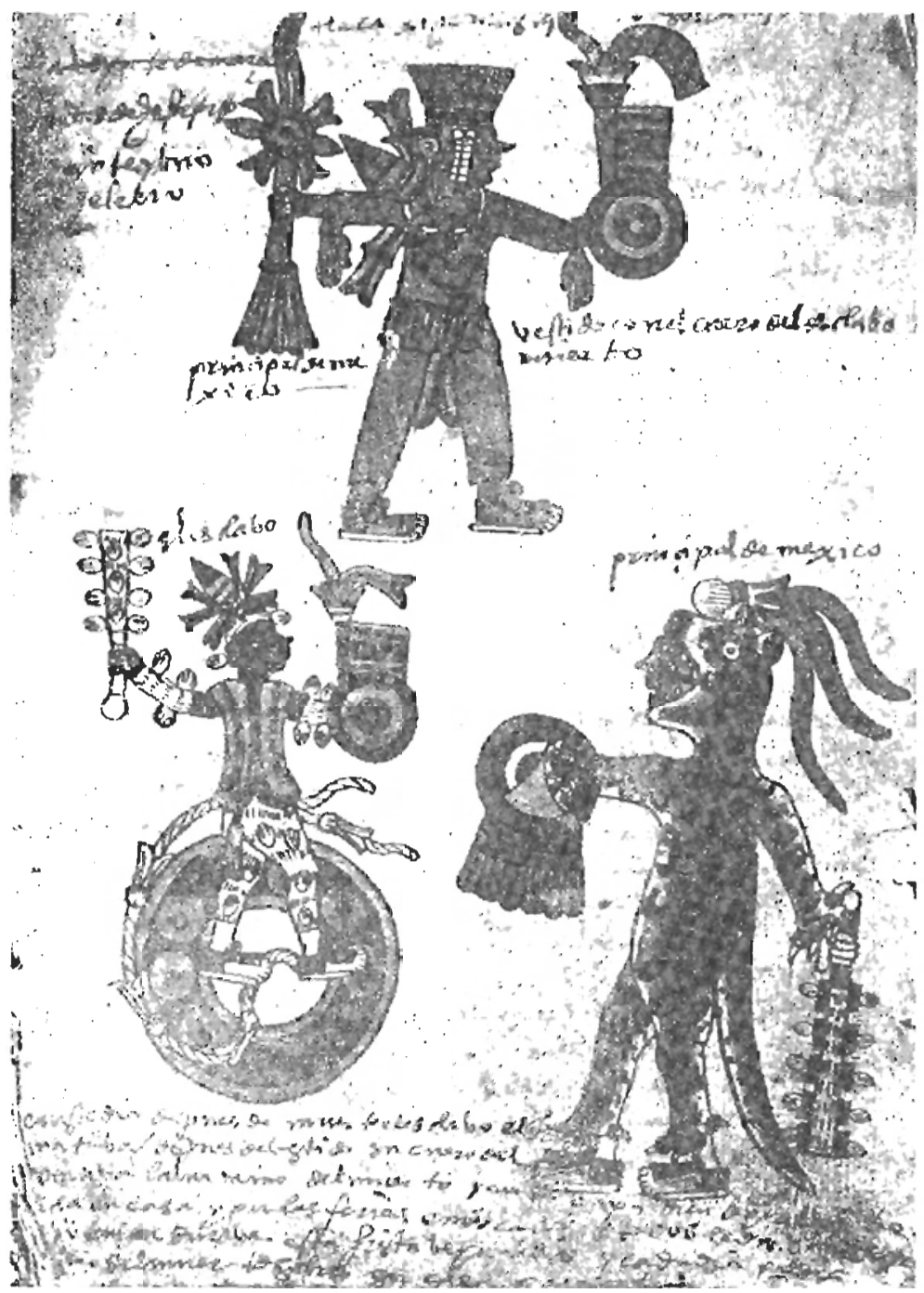

Fit; 19.-Gucreros aztecas con sus trajos característicos, sus chimallis y maquahicls, todo muy estilizado. De un códice poscolombiono (1554). Terito en españo) (Musco de América, Niadrid). 
otros tipos de trajes de guerra, diferentes a los aztecas de Méjico. Estas representaciones nos producen fuerte impresión por el cambio fundamental en el equipo militar que tuvicron los primeros conquistadores al pasar a combarir a Jos indígenas. Un gran cambio se produjo también con el armamento europeo occidental, con armas avanzadas y «modernas», con su

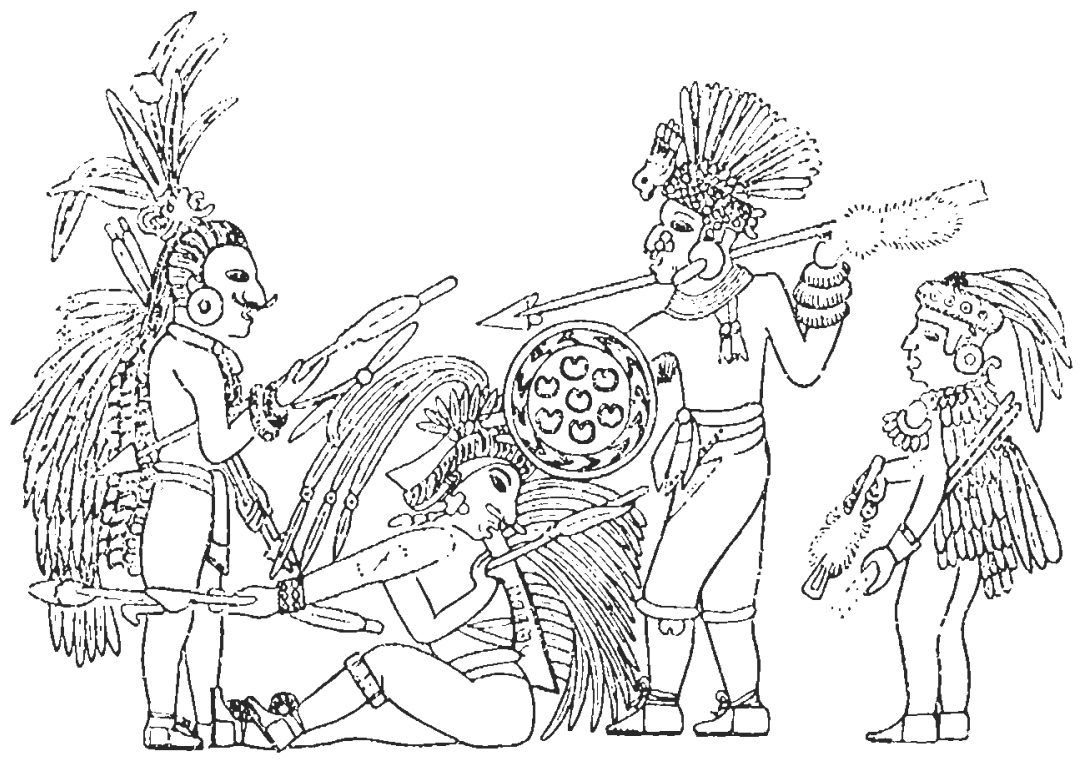

Fıg. 20.-Lucha entre mayas y aztecas. Pintura mural de Chichén Itzá, Yucatán. 'Tiencn escaupiles, estólicas y dardos.

técnica bastante mejorada; este cambio no tuvo lugar hasta el siglo xvir, pero especialmente después de 1630 , con las mcjores y más rápidas armas de fuego portátiles y con una artillería avanzada; todas las armas fueron fabricadas no sólo en España, sino también en otros países europeos y hasta en las nuevas fábricas de armas que habian surgido en Hispanoamérica. 


\section{BIBLIOGRAFIA SELECTA}

Aguado Bl.eye, Pedro: Mannal de Historia de España, II (Madrid, 1954), páginas 495.516.

Aguado, Pedro de: Historia de Sanla María y Nuevo Reino de Granada, con prólogo, notas y comentarios de Jerónimo Becker (Madrid, Impr. J. Rates, Publicaciones de la Real Academia de la Historia, 1916-1917).

American Museum of Natural History: General Guide (Nueva York, 1949).

BACON, Edwards: Civilizaciones extinguidas. Pueblos y culluras desaparecidas (ERIc J. Thompson: El ocaso de los dioses. Esplendor y decadencia de la cullura maya [Barcelona, Ed. Labor, S. A., 1965]).

Ballesteros y BaretTa, Antonio: Historia de España y su influencia en la bistoria iniversal (Barcelona, Salvat, 1918-1936).

Bnudealer, Adolphe F.: On the Art of War and Mode of Warfare of the Ancient Mexicans: «Records of the Peabody Museum of American Archaeology and Ethnology», 2 (1880), págs. 95-161.

Bennventf., Turibio de: Hisloria de los indios de la Nucva España (México, ChávezHaynos, 1941).

BrAm, Joseph: An Analysis of Inca Militarism (Monograph of the American Ethno. logical Suciety, IV; Nueva York, 1941).

Cingvirt, Albert F.: Spanish Arms and Ammontr (Londres-Nueva York, 1907).

Cifze de: Leún, Pedro de: Del señorio de los incas, prólogo y notas por Alberto Mario Salas (Buenus Aires, Solar, 1943).

Códice Azcatrt lán, Bibliothèque Nationale, París (siglo xvr).

Cónics: de Mendozh, Budleian Library, University of Oxford (siglo xvi).

Cooper Clark, James (ed.): Codex Mendoza. The Mcxicun Manuscripl know as the Collection of Mendoza and Preserved in the Bodleian Library, Oxford, editado y traducido por James Cooper Clark (Londres, Waterloo and Sons, 1938).

CorTés, Fernando: Carlas de relación de Fernando Corlés sobre el descubrimicuto y conquista de la Nueva España (Biblioteca de Autores Españoles, tomo 22), páginas $1-153$.

Contés, Hernán: En la serie de Grandes de lodos los ticmpos, texto de Roberto Boat (Madrid, Prensa Española, S. A., s. a.).

Cokrés, Hernán: Carlas de la conquista de México (Biblioteca de la Historia; Barcolona, 1985).

Chavero, Alfredo: Licnzo de Tlaxcala, 2 vols. (Méjico, Impr, del Timbre, 1892).

Divir:s. N.: Die Azleken, Meister in der Slantskunst (Schöpler hoher Kulturen, s. 1., 1974).

Demakin, Rafael M.: Historia de las armas de fuego en la Argentina, 1530-1852 (Buenos Aires, 1972).

Dínz del Castrelo, Bernal: Verdadera historia de los sucesos de la conquista de la Nueva España, por el capitán Diaz del Castillo, uno de los conquisiadores, prólogo de Carlus Pereyra (Biblioteca de Autores Españoles, tomo 26; Madrid, Espasa-Calpe, 1928), págs. 1-317.

Dinz del Castillo, Bernal: Historia verdadera de la conquista de la Nueva España, I-II (Biblioteca de la Historia; Barcelona, Sarpe, 1985).

Doror, Angel: Hernán Corlés. Un conquistador invencible (Madrid, s. a.).

Durín, Diegu: Historia de las Indias de Nueva España y Islas de Tierra Firne (siglo XVI), publicado por J. P. Ramírez (México, Impr. Andrada y Escalante, 1867).

Fernández Vega, Pilar: Guía del Museo de América (Madrid, 1965).

Gentleman of Elvas: The Narrative of the Expedition of Hernando de Soto, by 
the Genllemin of Elvas, en Frederich W. Honges y Theodore H. Lewis (eds.): Spunish Explorers in the Soutbern United States, $1528-1549$ (Nucva York, 1907).

GHeyn, Jacques de: Maniemont d'Arnes, d'Arquebuses, Mousquetz el Pique's (Amsierdam, 1608).

Gonoy, Diego: Relación becha por Dicgo Godoy a Hernando Cortés (Biblioteca de Autores Españoles, tumo 22, paigs. 465-470).

Grnhai, R. B. Cunningham: Los caballos de la conquista (Buenos Aires, Ed. Guillermo Krafi, 1948).

Gran Enciclopeda España y Amrírica, tomos I y IV: El descubrimienlo (siglo XVsiglo XVI) (Madrid, Espasa-Calpe, 1983).

InCa Garcilaso dí la Vega: Coménlutios reales de los incas, edición al cuidado de Angel Rusenblat, prólogo de Ricardo Rojas, con «Glosario de voces indígenas» (Bucnos Aires, ${ }^{2} 1945$ ).

Kingsborough, E. K. (Lord): Antiquities of Mexico (Londres, 1838-1840).

Las Cisas, Bartolomé de (Fray): Historia de las Indias (Madrid, Aguilar, s. a.).

López de Gómara, Francisco: Hispania Victrix, primera y segunda parte de la Historia general de las Indias, con lodo el descubrimiento y' cosas nolables basta al año 1551. con la conquista do México y de la Nueva España (Biblioteca de Autures Españoles, tomo 22; Madricl, 1877).

Lummis, Charles F.: Los exploradores españoles del siglo XVI (Madrid, EspasaCalpe [Col. Austral, n." 514], " $196(0)$.

Mndnkinga, Salvador de: Hernán Corlés (Buenos Aires, 1941).

Morley, Sylvanus $G$.: La civilización maja (Buenos Aires, 1947).

Morales Padrón, Francisco: Hisloria de España, en Manual de Historia Universal, tomo IV (Madrid, Espasa-Calpe, 1962).

Muñoz Camno, Diego: Historia de Tlaxcala, publicada y anotada por Alfredo Chavero (México, 1892).

Nutral,L, Zelia: The Allat or Spear-Thrower of the ancient Mexicans, en «Archaeology and Ethnology» (Papers of the Pcabody Muscum), tomo 1, núm. 5 (1891), págs. 173-205.

Nu'lad., Zelia: (On ancienl Mexican Shields, en «International Archiv für Ethnographie», tomo 5 (1892), págs. 34.53.

Pfirlyra, Carlos: Hermán Cortés (Buenos Aires, Espasa-Calpe [Col. Austral, n.o 23], 1942).

Payne-Gnllwey, Ralph (Sir): The Crossbow (Londres, 1903).

Petrkson, Harold L.: Arms and Armour in Colonial America, 1526-1783 (Nueva Yolk. 1956).

Peterson, Harold L.: Round Shot and Rammers. A Slackpole Book (Harrisburg, Pa., 1969).

Pidnl, Ramón Menéndez: El padre De las Casas. Su doble personalidad (Madrid, Espasa-Calpe, 1963).

Pijońn, José: Summa Artis, X (Madrid, Espasa-Calpe, 1964).

Prescott, William H.: History of the Conquest of Mexico (Nucva York, 1843).

Prescott, Willian H.: History of the Conquest of Peru (Nueva York, 1847).

Presco't, William H.: History of the Conquest of Pera, con comentarios (LondresNueva York, Everyman's Library-Ed. Ernest Rhys, 1907).

PRESCo'l"r, William H.: Die Eroberung Mexicos, Aus dem amerikaniscben von J. H. Eberly und B. Cramer-Neuhans (Munich, Beck, 1984), 390 págs. (Abbd.); Beck'sche Sonderausgaben, edición abreviada de Erich Marx (Leipzig, 1972).

Relación becha por Pedro Albaredo y Hernán Corlés, en que se reficren a las guerras y balallas para pacificar las provincias de Chapotulan, elc. La quema de sus caciques (Biblioteca de Autores Españoles, tomo 22; Madrid, s, a.), págs. 458-459. 
Samagún, Bernardino de (Fray): Historia general de las cosas de Nueva España (México, P. Robledo, 1938).

Sáenz de Santa Maria, Carmelo: Historia verdadera de la conquista de la Nueva España (Madrid, Instituto Gonzalo Fernández de Oviedo, 1982).

Salas, Alberto Mario: Las ammas de la conquista (Buenos Aires, 1950).

SPECIT, F. A. G. von: Gescbichle der Walfen nacbgewiesen und erlantert durch dic Kullurentwicklung der Völker und Bescbreibung der Wallen, vol. II, 1 (BerlínLeipzig, 1872).

Stone, George Cameron: A Glossary of the Construction, Decoration and Use of Arms and Amonr (Portland-Maine, 1934; ed. española, 1983).

Vallinni, George Clark: La Civilization Azleca (México, Fondo de Cultura Económica, 1944).

Vhlencia de Don Junn, Conde de: Calálogo bistórico-descriptivo de la Real Ammería de Madrid (1898).

Vición, Jorge: Historia de la artillería española (Madrid, CSIC, 1947).

Vigón, Jorge: El ejército de los Reyes Calólicos (Madrid, 1968).

Wevaïller, François: Histoire dn Mexique des origines à nous jours. Le Coteau Roanne (Éditions Horwath [Col. Histoire des Nations], 1984), 391 págs. 